\title{
Nulidades contractuales en el derecho público
} uruguayo

\author{
Carlos E. Delpiazzol
}

\section{RESUMEN}

Las nulidades contractuales son fruto de la inobservancia de una regla de derecho. Esta constatación, común a las distintas disciplinas, tiene relevancia en los contratos públicos que carecen de una regulación positiva específica sobre el tema. Ello permite valorar las patologías contractuales a partir de la clasificación clásica que distingue las nulidades de carácter subjetivo, referidas tanto a la administración como al contratista, y las objetivas, referidas al objeto y la causa ilícitas, con el complemento de las derivadas de vicios formales. Pese a la remisión que se hace al Código Civil para la distinción entre nulidad y anulabilidad, así como para la apreciación de las distintas causales de nulidad, las particularidades del contrato público imponen apreciaciones especiales, derivadas de los intereses afectados, la buena fe contractual, la importancia de la publicidad y concurrencia, la razonabilidad, inherente a las actuaciones administrativas, y la interpretación especial de los contratos.

Palabras clave: contratación pública, contrato administrativo, nulidades, anulabilidad, buena fe contractual.

1 Doctor en Derecho y Ciencias Sociales de la Universidad Mayor de la República Oriental del Uruguay, Montevideo, Uruguay. Director de la Especialización y Maestría en Derecho Administrativo y Gestión Pública de la Facultad de Derecho de la misma universidad. Catedrático de Derecho Administrativo en dicha Maestría y en la Facultad de Derecho de la Universidad de Montevideo, Montevideo, Uruguay. Correo-e: carlos.delpiazzo@delpiazzo. com. Enlace ORCID: https://orcid.org/0000-0001-6047-5890. Fecha de recepción: 30 de julio de 2020. Fecha de modificación: 10 de septiembre de 2020. Fecha de aceptación: 30 de septiembre de 2020. Para citar el artículo: DelPiAZZO, CARLOS E., "Nulidades contractuales en el derecho público uruguayo", Revista digital de Derecho Administrativo, Universidad Externado de Colombia, n. ${ }^{\circ}$ 25, 2021, pp. 109-143. DOI: https://doi.org/10.18601/21452946.n25.04. 


\section{Contractual Nullities in Uruguayan Public Law}

\section{ABSTRACT}

Contractual nullities are the result of non-compliance with a rule of law. This observation, common to different disciplines, is relevant to public contracts that lack a specific positive regulation on the subject. This allows to assess contractual pathologies from a classic classification that distinguishes the subjective nullities (pertaining to both the administration and the contractor), the objective nullities (referring to the illegal object and cause of the contract), and the additional nullities derived from formal vices. Despite a referral to the Civil Code to distinguish between nullity and voidability, as well as for the appreciation of different grounds for nullity, the particularities of the public contract impose special assessments derived from the nature of the affected interests, the contractual good faith principle, the importance of publicity and competition, the reasonableness inherent to administrative actions, and the special interpretation of contracts.

Keywords: Public Procurement, Administrative Contract, Nullities, Voidability, Contractual Good-Faith.

\section{INTRODUCCIÓN: REALIDAD DE BASE EN EL DERECHO URUGUAYO}

Existen institutos que no son propios de una determinada parcela científica del derecho, sino que pertenecen al campo de la teoría general, como es el caso del contrato ${ }^{2}$, la responsabilidad ${ }^{3}$, el dominio o propiedad ${ }^{4}$, y otros que no pueden ser acotados a las fronteras de una disciplina concreta. Si bien muchas categorías jurídicas han tenido un desarrollo preeminente en una determinada disciplina, no es suficiente para concluir que esa institución pertenece de manera exclusiva a una rama del derecho. En realidad, la mayoría de las figuras jurídicas trascendentes son comunes a los distintos sectores del ordenamiento, sin perjuicio de matices susceptibles de ser analizados desde distintos ángulos o perspectivas. Tal es el caso de la nulidad, carente de una regulación positiva del tema y de un tratamiento específico por las obras generales del derecho

2 Carlos E. Delpiazzo, Manual de contratación administrativa, t. I, 3. ${ }^{\text {a }}$ ed., Montevideo: Editorial Universidad Montevideo, 1997, pp. 19 y ss.; Contratación administrativa, Montevideo: Editorial Universidad Montevideo, 2005, pp. 10 y ss.; y Derecho administrativo general, vol. 1, 2. ${ }^{\text {a }}$ ed., Montevideo: A.M.F., 2015, pp. 404-405

3 Carlos E. Delpiazzo, Estudios sobre la responsabilidad de la Administración, Montevideo: U.M, 2009, pp. 41 y ss.; y Derecho administrativo general, vol. 2, Montevideo: A.M.F., 2013, pp. 457 y ss.

4 Carlos E. Delpiazzo, Derecho administrativo general, óp. cit., pp. 101 y ss. 
administrativo nacional y, por ende, requerida de una mirada desde la teoría general no excluyente del reconocimiento de particularidades o especies dentro del género. Consideramos que esa base conceptual común, comprensiva tanto de los actos como de los contratos ${ }^{5}$, resulta ineludible a partir de la constatación de que en la raíz del fenómeno de la nulidad se encuentra siempre la inobservancia de una regla de derecho, de modo que "el desajuste causa la nulidad, con la consiguiente ineficacia del acto o contrato no arreglado al precepto". Consecuentemente, nuestra legislación llama vicios "a todas las causas de imperfección, insuficiencia, deficiencia, etc., que puedan aquejar al acto".

En opinión de Eduardo J. Couture, la nulidad es el "vicio de que adolece un acto jurídico, cuando se ha verificado con violación o apartamiento de ciertas formas, o con la omisión de los requisitos indispensables para la validez del mismo" ${ }^{\prime \prime}$. Más precisamente, expresa Adolfo Gelsi Bidart ${ }^{8}$, seguido por Enrique Vescovi ${ }^{9}$, que por nulidad se entiende tanto el defecto (vicio) como el estado que ese defecto produce y las consecuencias de ese estado (invalidez o ineficacia). Por eso, bien ha dicho Agustín Gordillo que el concepto de nulidad no constituye sino una relación entre otros conceptos: la relación en virtud de la cual el derecho asigna a un hecho una determinada consecuencia jurídica ${ }^{10}$. Consecuentemente, una teoría general de las nulidades, por encima de las distintas ramas del derecho, debe responder a las consecuencias derivadas de determinados supuestos de antijuridicidad, los cuales dependerán del derecho positivo aplicable.

\section{REGULACIÓN NACIONAL DE LOS CONTRATOS PÚBLICOS}

En el derecho uruguayo no existe una disciplina legal orgánica en materia de contratación pública y, por ende, se carece de una regulación específica de las nulidades. A dicho minimalismo normativo se opone un abundante conjunto de disposiciones que regulan primordialmente los diversos procedimientos administrativos de formación de los contratos y múltiples normas dispersas referentes

5 Ibíd., pp. 321 y ss.; y 447 y ss.

6 Jorge Gamarra, Tratado de derecho civil uruguayo, t. XVI, Montevideo: Fundación de Cultura Universitaria, 1974, pp. 10-13.

7 Eduardo J. Couture, Vocabulario jurídico. Buenos Aires: Depalma, 1976, p. 423.

8 Adolfo Gelsi Bidart, De las nulidades en los actos procesales, Montevideo: A.M.F., 1981, pp. 93 y ss.

9 EnRIQue Vescovi, Derecho procesal civil, t. III, Montevideo: Idea, 1975, pp. 54 y ss., y EnRIQUe Vescovi (dir.), Código General del Proceso comentado, anotado y concordado, t. 2, Montevideo: Abaco, 1993, pp. 404 y ss.

10 Agustín Gordillo, Tratado de derecho administrativo, t. 3, 4. ${ }^{a}$ ed., Buenos Aires: Fundación de Derecho Administrativo, 1999, p. XI-2. 
a distintos aspectos particulares de los contratos posibles ${ }^{11}$. Prescindiendo de otros antecedentes, que pueden calificarse de remotos, puede señalarse como punto de partida la aprobación de la Ley n. ${ }^{\circ} 9.542$ de 31 de diciembre de 1935, conforme con la cual se estableció la obligatoriedad de la licitación pública para toda obra o inversión de fondos de importancia ${ }^{12}$.

En un segundo momento, debido a que la contratación pública implica normalmente un egreso de fondos para la Administración y a veces un ingreso de recursos, no es de extrañar que muchas disposiciones relativas a la materia se hayan incluido en normas presupuestales. Entre ellas, merece especial destaque el artículo 512 de la Ley n. ${ }^{\circ} 13.640$ de 26 de diciembre de 1967, en virtud del cual el Poder Legislativo autorizó al Poder Ejecutivo "a poner en vigencia, por vía reglamentaria y con carácter experimental, de acuerdo con el Tribunal de Cuentas, las bases del sistema de registración, administración y contralor financiero, contenidas en el Proyecto de Ley de Contabilidad y Administración Financiera aprobado por el Tribunal de Cuentas, dando cuenta a la Asamblea General". Al amparo de la citada norma legal, se dictó el Decreto n. ${ }^{\circ}$ 104/968 de 6 de febrero de 1968, disponiéndose la aplicación del referido proyecto por parte de todos los organismos estatales, conteniendo una sección dedicada a los "contratos del Estado" (artículos 29 a 61) ${ }^{13}$.

En un tercer momento, dicho reglamento recibió reconocimiento legislativo a través de los artículos 450 a 592 de la Ley n. ${ }^{\circ} 15.903$ de 10 de noviembre de 1987, superando así algunas vacilaciones interpretativas acerca del rango normativo del contenido del anterior Decreto n. ${ }^{\circ} 104 / 968^{[14]}$.

En un cuarto momento, en el año 1990, a través de un proceso de consultas y reflexión que contó con la participación de todos los organismos involucrados, se gestó un conjunto de reformas que fueron aprobadas en los artículos 653 a 660 de la Ley n. ${ }^{\circ} 16.170$ de 28 de diciembre de $1990^{[15]}$, encomendándose al Poder Ejecutivo (artículo 656) "la confección de un Texto Ordenado de las Normas sobre Ordenamiento Financiero contenidas en el artículo 450 y siguientes de la Ley n. ${ }^{\circ} 15.903$ de 10 de noviembre de 1987 y sus modificativas". Dicho mandato fue cumplido por el Poder Ejecutivo a través del Decreto n. ${ }^{\circ}$ 95/991 de 26 de febrero de 1991, cuyo artículo 6. ${ }^{\circ}$ autorizó su cita como "Texto

11 Carlos E. Delpiazzo, Normas y principios de la contratación administrativa, Montevideo: F.C.U., 2002, p. 9 y ss.; y "La contratación pública en Uruguay", en José A. Moreno Molina y Andry Matilla Correa (coords.), Contratos públicos en España, Portugal y América Latina, Madrid: Difusión, 2008, pp. 707 y ss.

12 Enrique Sayagues Laso, La licitación pública, Montevideo: Acali, 1978, p. 16.

13 Carlos E. Delpiazzo, "El Proyecto de Ley de Contabilidad y Administración Financiera. Consideraciones acerca de su jerarquía normativa", La Justicia Uruguaya, t. LXXVIII, 2009, pp. 45 y ss.

14 Carlos E. Delpiazzo, "Acerca de una reciente modificación al Proyecto de Ley de Contabilidad y Administración Financiera", Anales del Foro, n. ${ }^{\circ} 46,1983$, pp. 18 y ss.

15 Alberto Sayagues Areco, El nuevo régimen de compras, Montevideo: F.C.U., 1991, pp. 39 y ss. 
Ordenado C.A.F." o "TOCAF"16. Dicho primer TOCAF mantuvo una sección dedicada a los "contratos del Estado" (artículos 33 a 67), regulando fundamentalmente los procedimientos de contratación ${ }^{17}$, el que sufrió distintas modificaciones en los años sucesivos. Dichas modificaciones parciales condujeron a la aprobación del segundo TOCAF por el Decreto n. ${ }^{\circ} 194 / 997$ de 10 de junio de $1997^{[18]}$.

En un quinto momento, en virtud de los artículos 13 a 57 de la Ley n. ${ }^{\circ} 18.834$ de 4 de noviembre de 2011, se dedicó el capítulo I de su sección III a modificar el régimen de "Compras estatales" y su control por el Tribunal de Cuentas ${ }^{19}$. Atento a la calidad y cantidad de los cambios introducidos, el artículo 55 de dicha ley encomendó al Poder Ejecutivo la actualización del TOCAF, dando cuenta a la Asamblea General, y el artículo 56 cometió a la Agencia de Compras y Contrataciones del Estado su difusión. Agregó el artículo 57 que "Las normas referidas a la Ley de Contabilidad y Administración Financiera del Estado incluidas en este capítulo entrarán en vigencia el primer día del mes siguiente al de la publicación en el Diario Oficial del Texto Ordenado, excepto las normas referidas al Registro Único de Proveedores del Estado, que entrarán en vigencia a partir de la puesta en marcha del mismo, fecha que será dispuesta en la reglamentación ${ }^{\prime 2}$. En cumplimiento del mandato legislativo, el Poder Ejecutivo emitió el Decreto n. ${ }^{\circ}$ 150/012 de 11 de mayo de 2012, el cual aprueba el actual TOCAF $^{21}$ que, con ajustes posteriores ${ }^{22}$, contiene un conjunto de disposiciones de lo que sigue denominándose "contratos del Estado" (artículos 33 a 79), y que comprende las siguientes materias: normas sobre procedimientos (artículos 33 a 37 y 44 a 46), normas sobre determinados contratos (artículos 40 a 44), normas relativas a los pliegos de condiciones (artículos 47 y 48), normas sobre publicidad (artículos 50 a 56), normas sobre preferencias (artículos 57 a 62), normas sobre las ofertas y sus garantías (artículos 63 a 65), normas sobre admisibilidad, conveniencia y adjudicación de las ofertas (artículos 66 a 68), y normas sobre celebración y ejecución contractual (artículos 69 a 79).

16 Carlos E. Delpiazzo, "Génesis y evolución del tocaF", en Carlos E. Delpiazzo (coord.), Comentarios al TOCAF sobre la Hacienda Pública, Montevideo: U.M., 2012, p. 11 y ss.; y Texto Ordenado de la Ley de Contabilidad y Administración Financiera, 2. ${ }^{a}$ ed., Montevideo: Editorial Universidad, 1996.

17 Carlos E. Delpiazzo, Manual de contratación administrativa, t. I, Montevideo: Pronade, 1992 pp. 159 y ss.

18 Carlos E. Delpiazzo, Texto Ordenado de Contabilidad y Administración Financiera, 8. ${ }^{a}$ ed., Montevideo: F.C.U., 2010.

19 Alberto Sayagues Areco, Reformas al sistema de compras estatales, Montevideo: Alberto Sauagués 2011, pp. 119 y ss.

20 Carlos E. Delpiazzo, "A propósito del tercer Tocaf", La Justicia Uruguaya, t. 146, 2012, pp. 3 y ss.

21 Carlos E. Delpiazzo, Texto Ordenado de Contabilidad y Administración Financiera, 9. a ed., Montevideo: F.C.U., 2012.

22 Carlos E. Delpiazzo, Texto Ordenado de Contabilidad y Administración Financiera, 13. ${ }^{a}$ ed., Montevideo: F.C.U., 2018. 
Paralelamente, con la aprobación de la Ley n. ${ }^{\circ} 18.786$ de 19 de julio de 2011 , se reguló con detalle el contrato de participación público-privada, convirtiéndolo en el primer contrato que tiene una ley específica ${ }^{23}$, rigiéndose los demás, en cuanto a su objeto por normas aisladas o previsiones contenidas en los pliegos de condiciones. Algo similar ocurrió con la minuciosa regulación del contrato de concesión de explotación de minería de gran porte por imperio de los artículos 23 a 38 de la Ley n. ${ }^{\circ} 19.126$ de 11 de septiembre de $2013^{[24]}$.

\section{CONSIDERACIÓN DE LAS PATOLOGÍAS CONTRACTUALES}

Con las dos excepciones señaladas, en la medida que la regulación que sintéticamente viene de describirse refiere más a los procedimientos que debe seguir la Administración para contratar que a los contratos en sí mismos, es lógico inferir que los supuestos de antijuridicidad que pueden verificarse, tienen que ver más con los actos (preparatorios y de ejecución) que con los contratos propiamente dichos. De todos modos, las denominadas irregularidades ${ }^{25} \mathrm{o}$ patologías ${ }^{26}$ en la contratación pública pueden derivar de vicios precontractuales o contractuales: precontractuales serán aquellos que afectan al procedimiento y pueden incidir en el contrato y contractuales serán aquellos que afectan al contrato en sí mismo. Atendiendo al criterio de los elementos esenciales del contrato, los vicios pueden examinarse según afecten a alguno de los mismos, o sea, el elemento subjetivo, el elemento objetivo, el elemento teleológico y el elemento formal.

\subsection{Vicios del Elemento SUbJetivo}

Al estudiar los vicios que pueden afectar al elemento subjetivo del contrato hay que distinguir entre aquellos referidos a la Administración y aquellos relativos al cocontratante ${ }^{27}$. Respecto a la Administración, puede ocurrir que exista incompetencia, falta de crédito presupuestal, falta de autorización para contratar o vicios en la voluntad.

23 Carlos E. Delpiazzo (coord.), Comentarios a la ley de participación público privada, Montevideo: U.M., 2012, pp. 11 y ss., y "PPP y concesiones en Uruguay", en Bruno Cavalcanti y Andry Matilla (coords.), Estudios latinoamericanos sobre concesiones y PPP, São Paulo: Ratio Legis, 2013, pp. 299 y ss.

24 Natalia Veloso Giribaldi, "Especificidades de los proyectos mineros de gran porte", en Carlos E. Delpiazzo y Hernán Celorrio (coords.), Derecho minero uruguayo, Montevideo: A.M.F., 2015, pp. 153 y ss.

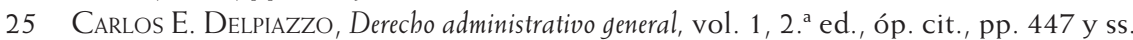

26 Carlos E. Delpiazzo, Contratación administrativa, 2. ${ }^{a}$ ed., Montevideo: F.C.U., pp. 309 y ss.

27 Carlos E. Delpiazzo, "Acerca de los sujetos en los contratos públicos", Estudios de Derecho Administrativo, n. ${ }^{\circ} 8,2013$, pp. 87 y ss. 
En primer lugar, en cuanto a la incompetencia de la Administración, ella puede ocurrir por razón de materia, territorio, grado y tiempo ${ }^{28}$ : a) existe incompetencia material cuando el órgano actúa en un ámbito ajeno a su competencia, invadiendo o no la esfera de actuación de otros órganos; b) existe incompetencia por razón de territorio en el caso de aquellos órganos públicos que tienen su competencia acotada geográficamente, cuando se actúa fuera de ella $;$ c) existe incompetencia de grado cuando actúa un órgano subordinado debiendo hacerlo el superior o a la inversa (en los supuestos de desconcentración privativa); y d) existe incompetencia en razón de tiempo cuando los órganos públicos tienen cronológicamente acotado el ejercicio de su competencia, como cuando actúan por turnos. En todos estos casos de incompetencia, se entiende que hay invalidez del acto emanado del órgano incompetente y la misma puede proyectar sus efectos sobre el contrato.

En segundo lugar, otro vicio que afecta al elemento subjetivo desde el punto de vista de la Administración es la falta de crédito presupuestal cuando del contrato a celebrar se deriva un gasto. De acuerdo con el TOCAF, las asignaciones presupuestales constituyen créditos abiertos a los organismos públicos para realizar sus gastos (artículo 13) y no podrán comprometerse gastos sin que exista crédito disponible (artículo 15). Además, los créditos no podrán destinarse a finalidad u objeto que no sean los enunciados en la asignación respectiva (artículo 16). Se entiende que la falta o insuficiencia de crédito presupuestal vicia el elemento subjetivo del acto, pero este vicio no provoca la nulidad, sino que genera responsabilidad tanto en el orden patrimonial, como eventualmente en el orden disciplinario y político, según la jerarquía del ordenador respectivo.

En tercer lugar, la falta de autorización para contratar requerida en algunos supuestos vicia también el elemento subjetivo, por cuanto el órgano público actuante lo está haciendo sin que se haya removido el obstáculo necesario para que lo haga mediante el dictado de la pertinente autorización. En este caso, se entiende que el vicio puede ser saneado hasta el momento previo a la notificación de la adjudicación, o sea, que existe un vicio, pero el mismo tiene una trascendencia relativa y puede ser objeto de saneamiento posterior.

Por último, pueden existir vicios que afecten a la voluntad, ya que los órganos públicos expresan su voluntad a través de la manifestación de 
voluntad natural de las personas físicas que los animan y esa voluntad puede estar viciada por error, violencia, dolo u otros vicios propios del consentimiento.

En cuanto al cocontratante, pueden darse los siguientes vicios: incapacidad, presencia de impedimentos para contratar con la Administración y vicios en la voluntad ${ }^{29}$.

Un primer vicio es el relacionado con la incapacidad del proponente vicia el acto de oferta y cuando este vicio incide en la formación de la voluntad administrativa, genera vicios en esta que se proyectan a la adjudicación y eventualmente al contrato. Asimismo, se tiene que la existencia de impedimentos para contratar con la Administración resulta de disposiciones legales relativas a prohibiciones e incompatibilidades al respecto. Así, al tenor del artículo 46 del TOCAF se dispone que "Están capacitados para contratar con el Estado las personas físicas o jurídicas, nacionales o extranjeras, que teniendo el ejercicio de la capacidad jurídica que señala el derecho común, no estén comprendidas en alguna disposición que expresamente se lo impida o en los siguientes casos: a) Ser funcionario público de la Administración contratante o mantener un vínculo laboral de cualquier naturaleza con la misma, no siendo admisibles las ofertas presentadas por este a título personal, o por personas físicas o jurídicas que la persona integre o con las que esté vinculada por razones de representación, dirección, asesoramiento o dependencia. No obstante, en este último caso de dependencia podrá darse curso a las ofertas presentadas cuando no exista conflicto de intereses y la persona no tenga participación en el proceso de adquisición. De las circunstancias mencionadas, deberá dejarse constancia expresa en el expediente; b) Estar suspendido o eliminado del Registro Único de Proveedores del Estado; c) No estar inscripto en el Registro Único de Proveedores del Estado de acuerdo con lo que establezca la reglamentación, d) Haber actuado como funcionario o mantenido algún vínculo laboral de cualquier naturaleza, asesor o consultor, en el asesoramiento o preparación de pliegos de bases y condiciones particulares u otros recaudos relacionados con la licitación o procedimiento de contratación administrativa de que se trate $_{;}$e) Carecer de habitualidad en el comercio o industria del ramo a que corresponde el contrato, salvo que por tratarse de empresas nuevas demuestren solvencia y responsabilidad". Por último, al igual que en el caso de la Administración, la voluntad del co-contratante puede estar viciada por error, violencia, dolo u otra circunstancia que la invalide. 


\subsection{Vicios del elEMENTO ObjeTIVO}

En cuanto a los vicios del elemento objetivo del contrato, es necesario considerar que el contenido del contrato debe ser lícito, determinado, cierto, ético y razonable ${ }^{30}$. La circunstancia contraria, es decir, que el objeto del contrato sea ilícito, indeterminado, incierto, falto de ética o irrazonable, determina un vicio del contrato. Al respecto, es valor entendido que se impone un examen casuístico para determinar si ese vicio es o no subsanable.

En la práctica, reviste interés referirse al vicio de irrazonabilidad, que puede derivar de contradicciones (por ejemplo, entre la parte expositiva y la parte dispositiva del acto de adjudicación) que se traduzcan en el contrato y que a veces incluso inviabilicen celebrarlo porque no se sabe cómo concretarlo. El vicio de irrazonabilidad también puede derivar de la falta de proporcionalidad o de lo que se denomina el objeto absurdo.

\subsection{Vicios del elemento teleológico}

Es obvio que la Administración, por su propia naturaleza instrumental, actúa en función de un fin público, al cual no es ajena su actividad contractual. Por eso, cuando cualquier órgano público actúa con una finalidad distinta o diversa de la propia del servicio de que se trate, excediendo de ese modo los poderes que le han sido otorgados, incurre en un vicio que afecta al elemento teleológico del contrato respectivo. Precisamente, en la desviación de poder se hace uso de facultades legales persiguiendo fines personales del agente público o extraños a la conducta querida por la regla de derecho ${ }^{31}$.

\subsection{ViCIOS DEL ELEMENTO FORMAL}

Siguiendo a Héctor Mairal, se estudiarán estos vicios a través de los distintos momentos en que pueden acaecer, distinguiendo entre los vicios anteriores al llamado, los vicios del llamado, los que pueden acaecer hasta el acto de apertura, los

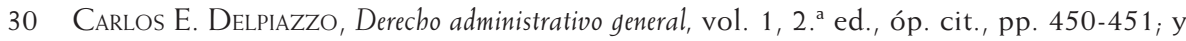
Contratación administrativa, 2. ${ }^{a}$ ed., óp. cit., pp. 311-312.

31 Carlos E. Delpiazzo, Derecho administrativo general, vol. 1, 2. ${ }^{a}$ ed., óp. cit., pp. 325-326; Julio A. Prat, De la desviación de poder, Montevideo: Facultad de Derecho y Ciencias SocialesBiblioteca de Publicaciones Oficiales, 1957, p. 342; y La desviación de poder, Montevideo: A.M.F., 1976, p. 123; Alberto Ramón Real, "Desviación de poder", Estudios de Derecho Administrativo, t. II, 1967, pp. 9 y ss.; Augusto Duran MartíneZ, "Desviación, abuso y exceso de poder", en Estudios de Derecho Administrativo. Parte general, Montevideo: ADM, 1999, pp. 131 y ss.; y Juan Pablo Cajarville Peluffo, Sobre derecho administrativo, t. II, 3. a ed., Montevideo: F.C.U., 2012, pp. 66 y ss. 
que tienen lugar en el acto de apertura, los que afectan la adjudicación y los posteriores a la adjudicación ${ }^{32}$.

En cuanto a los vicios anteriores al llamado, cabe diferenciar la falta de habilitación presupuestal -que acaba de referirse como un vicio que afecta más bien al elemento subjetivo en tanto una de las partes en la contratación administrativa es siempre una Administración- y la falta de autorización para contratar, sea que esa falta derive de la ausencia de ley o del establecimiento de un requisito legal a ser salvado para que por vía administrativa pueda la Administración respectiva llevar adelante la contratación. Un vicio relevante en esta etapa preparatoria es la omisión del procedimiento pertinente, sea licitación pública u otro que fuera requerido para el contrato respectivo. Si bien podría pensarse que tal situación produce la nulidad contractual por defecto de forma, en rigor se trata de un supuesto de responsabilidad administrativa que no puede proyectar consecuencias sobre el contrato celebrado con un tercero de buena fe.

Tratándose de los vicios del llamado en sí, los principales vicios que la doctrina señala son los que tienen que ver con la publicidad del mismo. Ya Enrique Sayagues Laso en su tesis de 1940 enseñaba que los defectos en la publicidad o la omisión de la publicidad pueden generar nulidad ${ }^{33}$. $\mathrm{Al}$ respecto, será necesario analizar casuísticamente la gravedad de esa omisión o de ese defecto, en orden a medir su trascendencia. Evidentemente, no es lo mismo que se haya padecido algún error tipográfico (que en definitiva es un defecto en la publicidad), que no haber publicitado el llamado, por ejemplo.

Con relación a los vicios hasta el acto de apertura, lo primero que corresponde señalar es la modificación unilateral por la Administración del pliego. En realidad, después del llamado la Administración no puede modificar el pliego y, si lo hace, esa modificación importa un nuevo llamado. Es obvio que algo tan elemental como es la modificación del día, lugar y hora de la apertura implica un nuevo llamado desde el punto de vista técnico. Otro tanto ocurre cuando se hacen aclaraciones a algunos oferentes y no a todos, porque en este caso se está violentando el principio de igualdad. También puede considerase un comportamiento vicioso de la Administración la exclusión de posibles oferentes, sea por la vía del pliego mismo, sea por la vía de requisitos registrales o de otro tipo, que excluyan de la posibilidad de ofertar a un número determinado

32 HéCtor A. Mairal, Licitación pública. Protección jurídica de los oferentes, Buenos Aires: Depalma, 1975 , pp. 25 y ss.

33 Enrique Sayagues Laso, La licitación pública, óp. cit., p. 80. 
o determinable de potenciales oferentes. Sobre este aspecto, el artículo 49 del TOCAF prevé que la comprobación de que en un llamado a licitación se hubieren formulado especificaciones, o incluido cláusulas cuyo cumplimiento solo sea factible para determinada persona o entidad, de manera que el llamado esté dirigido a favorecer situaciones particulares, dará lugar a su anulación inmediata en el estado del trámite en que se encuentre, y a la iniciación también inmediata del sumario pertinente para determinar los responsables.

Respecto a posibles vicios en el acto de apertura, ellos pueden derivar de circunstancias tales como la admisión de ofertas tardías, la exclusión inmotivada de ofertas presentadas en término, la omisión de labrar acta o la documentación sustancialmente incompleta del acta.

En cuanto a los vicios de la adjudicación, ellos pueden obedecer a diversos supuestos. El más claro es cuando no recae en la oferta que, ajustándose al pliego, sea la más conveniente a los intereses de la Administración y las necesidades del servicio. Pero también vician el acto administrativo decisorio, la adjudicación a oferta condicional y la adjudicación a oferta defectuosa. Esto último puede acontecer siempre que se verifiquen apartamientos relevantes de lo requerido, tales como la presentación de propuesta no firmada, con indicaciones no permitidas, con enmiendas no salvadas en partes sustanciales, con precios no ofrecidos de acuerdo con lo pedido o con otros defectos de similar naturaleza.

Asimismo, pueden configurarse vicios posteriores a la adjudicación en situaciones tales como la anulación de la adjudicación y contratación directa posterior sin que se configuren los supuestos para ello, o cuando las cláusulas del contrato contrarían manifiestamente las estipulaciones del pliego o las condiciones de la oferta sobre la cual recayó el acto administrativo decisorio.

\section{LA CUESTIÓN DE LA APLICABILIDAD DEL CÓDIGO CIVIL}

Para dimensionar la trascendencia jurídica de los referidos vicios contractuales, debe estarse al derecho positivo de cada país, el cual no es siempre explícito al respecto como lo evidencian los más recientes relevamientos comparados iberoamericanos ${ }^{34}$. Por tanto, cuando falta un tratamiento específico, como

34 José Antonio Moreno Molina y Andry Mantilla Correa, Contratos públicos en España, Portugal y América Latina, Madrid: Difusión Jurídica, 2008; Jaime Rodríguez Arana, Miguel A. Sendin y Jorge Danos, Contratación pública, Arequipa: Adrus, 2013; José Luis BenAvides y Pablo Moreno Cruz (eds.), La contratación pública en América Latina, Bogotá: Universidad Externado de Colombia, 2016; Jaime Rodrícuez Arana y Carlos E. Delpiazzo (eds.), Bases y retos de la contratación pública en el escenario global. Actas del XVI Foro Iberoamericano de Derecho Administrativo, Caracas: Editorial Jurídica Venezolana International, 2017; y ERNESTO JINESTA LOBO (coord.), El régimen de los contratos públicos, Bogotá: Temis, 2019. 
acontece en el derecho uruguayo, es lícito plantearse la interrogante de si es posible aplicar a los contratos públicos la disciplina de las nulidades contenidas en los códigos civiles y, en caso afirmativo, con qué alcance o hasta dónde. Para examinar esta ardua cuestión, corresponde distinguir entre los países que tienen regulaciones expresas del tema (a las que debe estarse) y los que no (donde es preciso acudir a soluciones generales) ${ }^{35}$.

\subsection{ENFOQUE COMPARADO}

Entre los derechos positivos que regulan las nulidades de los actos administrativos y de los contratos que celebra la Administración, cabe mencionar, a vía de ejemplo, Argentina y España. Así, en Argentina, la Ley Nacional de Procedimientos Administrativos n. ${ }^{\circ} 19.549$, con las reformas introducidas por la Ley n. ${ }^{\circ} 21.686$, dispone en su artículo 14 que "El acto administrativo es nulo, de nulidad absoluta e insanable, en los siguientes casos: a) cuando la voluntad de la Administración resultare excluida por error esencial; dolo, en cuanto se tengan como existentes hechos o antecedentes inexistentes o falsos; violencia física o moral ejercida sobre el agente ${ }_{i}$ o por simulación absoluta $;$ y b) cuando fuere emitido mediante incompetencia en razón de la materia, del territorio, del tiempo o del grado, salvo, en este último supuesto, que la delegación o sustitución estuvieren permitidas; falta de causa por no existir o ser falsos los hechos o el derecho invocados; o por violación de la ley aplicable, de las formas esenciales o de la finalidad que inspiró su dictado". Agrega el artículo 15 que "Si se hubiere incurrido en una irregularidad, omisión o vicio que no llegare a impedir la existencia de alguno de sus elementos esenciales, el acto será anulable en sede judicial". A partir de dichas normas, la doctrina ha construido la teoría de la invalidez administrativa sobre la base de la clasificación bipartita que distingue entre nulidad absoluta y relativa, descartando la categoría del acto administrativo inexistente y analizando la trascendencia jurídica de cada posible vicio del acto en particular ${ }^{36}$.

Con referencia a los contratos, en virtud del artículo 36 del Decreto de Necesidad y Urgencia n. ${ }^{\circ}$ 1023/2001 de 13 de agosto de 2001, se establece la aplicación directa a los mismos del título III de la citada ley nacional de procedimiento administrativo, relativo a los "Requisitos esenciales del acto administrativo", mediante la modificación del último párrafo del artículo $7 .^{\circ}$ de dicha ley, en los siguientes términos: "Los contratos que celebren las jurisdicciones y entidades comprendidas en el Sector Público Nacional se regirán por sus

35 Carlos E. Delpiazzo, "Notas acerca de las nulidades de los actos administrativos", Revista de Derecho Público, n. ${ }^{\circ} 42,2012$, pp. 30 y ss.

36 Juan Carlos Cassagne, Ley Nacional de Procedimientos Administrativos, Buenos Aires: La Ley, 2009, pp. 304 y ss., y Julio Rodolfo Comadira, Procedimientos administrativos, t. I, Buenos Aires: La Ley, 2002, pp. 276 y ss. 
respectivas leyes especiales, sin perjuicio de la aplicación directa de las normas del presente título, en cuanto fuere pertinente". Por lo tanto, se consideran aplicables a los contratos (bilaterales) los requisitos de validez, nulidad y anulabilidad de los actos administrativos (unilaterales) ${ }^{37}$.

Por su parte, en España, la ley de régimen jurídico de las Administraciones públicas y del procedimiento administrativo común, Ley n. ${ }^{\circ}$ 30/1992 de 26 de noviembre de 1992, prevé que la nulidad de pleno derecho de los actos administrativos se produce en los siguientes supuestos (artículo 62.1): a) los actos que lesionan los derechos y libertades susceptibles de amparo constitucional; b) los actos dictados por órgano manifiestamente incompetente por razón de la materia o del territorio; c) los actos que tengan un contenido imposible; d) los actos que sean constitutivos de infracción penal o se dicten como consecuencia de esta ${ }_{i}$ e) los actos dictados prescindiendo total y absolutamente del procedimiento legalmente establecido o de las normas que contienen las reglas esenciales para la formación de la voluntad de los órganos colegiados, f) los actos, expresos o presuntos, contrarios al ordenamiento jurídico, en virtud de los cuales se adquieren facultades o derechos, cuando se carezca de los requisitos esenciales para su adquisición; y g) en los supuestos que se establezcan expresamente mediante una disposición de rango legal. Añade el artículo 63 que "son anulables los actos de la Administración que incurran en cualquier infracción del ordenamiento jurídico, incluso la desviación de poder". De este modo, se distingue entre el régimen jurídico de la nulidad y de la anulabilidad de los actos administrativos ${ }^{38}$.

Con relación a los contratos, la Ley n. ${ }^{\circ}$ 30/2007 de 30 de octubre de 2007 dedica el capítulo $\mathrm{v}$ de su libro I al régimen de invalidez de los mismos ${ }^{39}$, estableciendo que "Además de los casos en que la invalidez derive de la ilegalidad de su clausulado, los contratos de las Administraciones públicas [...] serán inválidos cuando lo sea alguno de sus actos preparatorios o los de adjudicación provisional o definitiva, por concurrir en los mismos alguna de las causas de derecho administrativo o de derecho civil a que se refieren los artículos siguientes (artículo 31)".

Consecuentemente, se identifican causas de nulidad (artículo 32) y de anulabilidad (artículo 33), agregando que "La invalidez de los contratos por causas reconocidas en el derecho civil, en cuanto resulten de aplicación a los contratos a que se refiere el artículo 31 , se sujetará a los requisitos y plazos

37 Carlos A. Botassi, "Invalidez del contrato administrativo", en Juan Carlos Cassagne y Enrique Rivero Isern (dirs.), La contratación pública, t. 2, Buenos Aires: Hammurabi, 2006, pp. 966 y ss.

38 Juan Alfonso Santamaría Pastor, Principios de derecho administrativo general, t. II, Madrid Iustel, 2005, pp. 133 y ss.

39 Víctor Sebastián Baca Oneto, La invalidez de los contratos públicos, Navarra: Thomson Civitas, 2006, pp. 45 y ss. 
de ejercicio de las acciones establecidas en el ordenamiento civil, pero el procedimiento para hacerlas valer se someterá a lo previsto para los actos y contratos administrativos anulables".

A diferencia de dichos casos, en los derechos positivos que no regulan las nulidades de los actos administrativos y de los contratos que celebra la Administración, es necesario construir el régimen de nulidades a partir del principio de juridicidad como pilar fundamental del Estado de derecho ${ }^{40}$. En efecto, lo propio de todo ordenamiento jurídico es prever un comportamiento como debido o querido y, para el caso de su incumplimiento, determinar las consecuencias correspondientes. En tal sentido, ha sido tradicional en la ciencia jurídica la comprensión de la regla de derecho (en sentido amplio) -incluyendo tanto las normas (en sentido estricto) como los principios generales- a partir de la conjunción de dos elementos: el supuesto de hecho y la consecuencia jurídica, unidos ambos por un nexo. Siendo así, el acto administrativo o el contrato que celebre una Administración serán irregulares cuando estén viciados en sus elementos o presupuestos, siendo ilegítimo toda vez que resulte contrario a una regla de derecho, sea norma o principio general. Por consiguiente, si la sanción de la ilegitimidad consiste en una afectación de la eficacia formal del acto administrativo -la que se traduce en una fuerza activa y en una fuerza pasiva respecto al ordenamiento jurídico ${ }^{41}$ - este será inválido.

A su vez, la afectación de la eficacia formal del acto inválido puede tener distintos alcances según lo que disponga el derecho positivo, tales como ${ }^{42}$ : a) la nulidad del acto, es decir, la no producción de ningún efecto $;$ b) la producción de efectos distintos o parciales respecto a los que produciría un acto legítimo; c) la producción de los efectos propios del acto legítimo pero precarios, o sea, revocables en cualquier momento.

En orden lógico, similares consideraciones cabrán realizar respecto a los contratos públicos.

\subsection{ENFOQUE NACIONAL}

En Uruguay, el derecho administrativo contiene la referida noción de ilegitimidad, entendiendo por tal la contrariedad a la regla de derecho en los términos que la define el artículo 23.a del Decreto Ley n. ${ }^{\circ} 15.524$ de 9 de enero de 1984, como comprensiva de "todo principio de derecho o norma constitucional,

40 Carlos E. Delpiazzo, "Afirmación y evolución del principio de juridicidad. Vigencia del pensamiento de Maurice Hauriou", en Andry Matilla, Jaime Orlando Santofimio y Héctor Santaella (coords.), Ensayos de Derecho Público en memoria de Maurice Hauriou, Bogotá: Universidad Externado de Colombia, 2013, pp. 197 y ss.

41 Horacio Cassinelli MuÑoz, "Oposición superviniente: ¿derogación o inconstitucionalidad?", Revista Derecho, Jurisprudencia y Administración, t. 55, 1958, pp. 160 y ss.

42 Juan Pablo Cajarville Peluffo, Sobre derecho administrativo, óp. cit., pp. 12 y ss. 
legislativa, reglamentaria o contractual". Sin embargo, no establece, como ocurre en otros ordenamientos, una categorización por grados de invalidez y sus consecuencias. Por lo tanto, a partir del artículo 309 de la Constitución -que contiene dicha noción de regla de derecho- resulta que, en principio, toda violación de una regla de derecho por un acto administrativo produce su anulabilidad (en sentido amplio), la que puede verificarse tanto en vía administrativa (revocación) como en vía jurisdiccional (anulación en sentido estricto).

Si bien la competencia anulatoria en ejercicio de la función jurisdiccional ha sido reservada constitucionalmente al Tribunal de lo Contencioso Administrativo ${ }^{43}$, ello no enerva la posibilidad de que los distintos tribunales del Poder Judicial puedan juzgar sobre la validez de los actos administrativos relevantes para la causa sometida a su conocimiento y proceder a su desaplicación en el caso concreto ${ }^{44}$. En la medida que las consecuencias de la ilegitimidad de un acto administrativo dependen del derecho positivo, puede ocurrir que un acto irregular sea convalidado por otro posterior ${ }^{45}$. Confirmando el criterio de la anulabilidad, dentro del género saneamiento o convalidación, es posible distinguir varias especies: a) la ratificación es el acto por medio del cual el órgano competente reconoce como propio el dictado por el órgano incompetente subordinado, siendo sus efectos retroactivos ${ }_{i}$ b) la confirmación es el acto de subsanación del vicio que afecta a otro acto, dictado por el mismo órgano y con igual efecto retroactivo; c) la conversión es el acto por el cual se declara la voluntad de no desperdiciar los elementos válidos de un acto viciado, integrándolos al nuevo acto y extinguiendo sus elementos inválidos, lo que es factible cuando un acto irregular como tal puede valer como otro distinto, obviamente operando sus efectos hacia el futuro; $;$ d) la conservación es el

43 Carlos E. Delpiazzo, "La justicia administrativa en Uruguay", en Germán Cisneros, Jorge Fernández Ruiz y Miguel Alejandro López Olvera (coords.), Justicia administrativa, México: Unam, 2007, pp. 147 y ss.; "Los contenciosos administrativos de anulación y reparación en el derecho uruguayo", Revista de Derecho Público, n. ${ }^{\circ} 108,2006$, pp. 7 y ss.; y "Régimen contencioso administrativo uruguayo", en Jaime Rodríguez Arana y Marta García Pérez (coords.), La jurisdicción contencioso administrativa en Iberoamérica, Caracas: Editorial Jurídica Venezolana, 2014, pp. 437 y ss.

44 Horacio Cassinelli Muñoz, "Competencia del Poder Judicial para conocer la validez de un acto administrativo como premisa del fallo", Revista Derecho, Jurisprudencia y Administración, t. 71, 1971, pp. 94 y ss.; y Derecho constitucional y administrativo, Montevideo: La Ley Uruguay, 2010, pp. 743 y ss.; Agustín Prat y Gustavo Fischer, "Desaplicación en vía jurisdiccional de un acto administrativo ilegal por el cual se concedió el registro de una marca en violación de normas prohibitivas", Revista de Derecho Público, n. ${ }^{\circ} 2-3,1993$, pp. 113 y ss.; RubÉN Flores, "¿Es competencia exclusiva del Tribunal de lo Contencioso Administrativo el control jurisdiccional de los actos administrativos?", Anuario de Derecho Administrativo, t. VI, 1998, pp. 132 y ss.; y JuAN A. PISANO y RubÉN Flores, "¿Es siempre admisible el control de los actos administrativos por el Poder Judicial?", Anuario de Derecho Administrativo, t. VII, 1999 , pp. 107 y ss.

45 Carlos E. Delpiazzo, Derecho administrativo general, vol. 1, 2. ${ }^{\text {a }}$ ed., óp. cit., p. 323. 
acto por el cual la Administración decide mantener subsistente la parte válida del acto viciado, sin convertirlo.

Respecto a los contratos, la cuestión es más ardua porque disposiciones aisladas de derecho administrativo que hablan de nulidad parecen aludir a ella como vicio más que a sus consecuencias ${ }^{46}$. No obstante, con base en los aspectos conceptuales señalados, la nulidad en el campo contractual también responde a un defecto o apartamiento en sus elementos o presupuestos. Siendo así, como ocurre en los países carentes de regulación específica de la nulidad de los actos y contratos administrativos, adquiere especial trascendencia la interrogante acerca de la procedencia de hacer caudal de la disciplina civil de la invalidez de los actos jurídicos ${ }^{47}$.

Desde el derecho civil, a partir de los artículos 1559 a 1572 del Código Civil (y sus concordantes del Código de Comercio y del Código General del Proceso), se enseña que ${ }^{48}$ :

a. La nulidad absoluta o de pleno derecho se caracteriza por el carácter automático e inmediato de la invalidez (la cual se produce sin necesidad de impugnación judicial, cuya sentencia tiene, en todo caso, carácter declarativo), sus efectos erga omnes y su insubsanabilidad.

b. La anulabilidad o nulidad relativa se singulariza por tres rasgos opuestos: no posee carácter automático (requiriéndose pronunciamiento jurisdiccional a través de una sentencia constitutiva), solo puede ser alegada por las personas en cuyo beneficio se establece y puede subsanarse por el transcurso del tiempo o en virtud de su convalidación.

Desde el derecho administrativo, cuesta traspolar sin más los esquemas bipartitos de nulidad absoluta y relativa, y más aún los tripartitos que diferencian entre nulidad absoluta, nulidad relativa e inexistencia. En efecto, comenzando por el supuesto del acto inexistente, más allá de la contradictio in terminis que encierra la expresión, bien ha dicho el Tribunal de lo Contencioso Administrativo en su sentencia n. ${ }^{\circ} 388$ de 25 de julio de 2007, entre otras, que "Estos actos al no tener existencia no entran en el llamado plano existencial" ${ }^{\prime 4}$.

Respecto a las categorías de acto absolutamente nulo y de acto relativamente nulo, nuestro derecho público tampoco las recibe tal cual, sin perjuicio de la señalada posibilidad de diferenciar diversos grados de invalidez en un

46 Carlos E. Delpiazzo, "Nulidades en el derecho administrativo y el Código Civil", Doctrina y jurisprudencia de derecho Civil, t. IV, Montevideo: F.C.U., 2016, pp. 87 y ss.

47 Romeu Felipe Bacellar Filho, Direito Administrativo e o novo Código Civil, Belo Horizonte: Editora Forum, 2007, pp. 23 y ss.

48 Jorge Gamarra, Estudios sobre obligaciones, Montevideo: Medina, 1956, p. 56, y Tratado de Derecho civil uruguayo, óp. cit., pp. 131 y ss.; y Jorge Peirano Facio, Curso de obligaciones, t. VI, Montevideo: F.C.U., 1957, pp. 321 y ss.

49 Carlos E. Delpiazzo, "Nulidad absoluta, nulidad relativa e inexistencia en el derecho administrativo", Revista CADE de Doctrina y Jurisprudencia, t. XXXV, 2016, pp. 11 y ss. 
arco de casuística enorme que puede reagruparse, atendiendo a la gravedad de los vicios, en subsanables y no subsanables, siempre que la situación jurídica creada por el acto no impida su revisión ${ }^{50}$.

Habitualmente se señala como reparo para la aplicación del esquema de nulidades del Código Civil la incidencia de la presunción de juridicidad del acto administrativo y la ejecutoriedad del mismo. No obstante, tal postura no puede admitirse acríticamente, sino que también aquí se impone distinguir entre los países que consagran positivamente tales caracteres del acto administrativo y los que, en cambio, no lo hacen, como es el caso de nuestro país ${ }^{51}$. En rigor, más allá de los intentos por diferenciar las características de las nulidades en el derecho civil y en el derecho administrativo ${ }^{52}$, no son la presunción de juridicidad y la ejecutoriedad del acto administrativo los obstáculos para la aplicación de la teoría de las nulidades recogida ordinariamente en los códigos civiles sino el alcance subjetivo de estos, primordialmente dirigidos a regular las relaciones entre particulares. A falta de normas expresas de derecho público, la tentación de lo que ha dado en llamarse el "mimetismo respecto de las teorías del derecho civil" ${ }^{\prime 53}$, choca con un sistema de invalidez constituido en un derecho que encuentra su centro en el problema de la autonomía de los sujetos privados [por lo que] mal se presta a ser aplicado a un derecho que encuentra su centro en el problema de la dialéctica entre autoridad y libertad" ${ }^{\prime \prime 4}$. Sin embargo, la inaplicabilidad directa -literal, dice Agustín Gordillo ${ }^{55}$ - del Código Civil no implica desconocer los principios que recoge ni renunciar a priori a su invocación indirecta en orden a la anulabilidad.

50 Carlos E. Delpiazzo, "Estabilidad del acto administrativo generador de derechos", en Actas del VIII Foro Iberoamericano de Derecho Administrativo, Florida: Digital Publishing, 2009, pp. 753 y ss. $;$ y "Revocación del acto administrativo por razones de legitimidad y derechos adquiridos", en AA. VV., Seguridad jurídica y derecho administrativo, Montevideo: F.C.U., 2011, pp. 15 y ss.

51 Carlos E. Delpiazzo, "Caracteres del acto administrativo", en Visión actual del acto administrativo. XI Foro Iberoamericano de Derecho Administrativo, Santo Domingo: Finjus-Adda 2012 , pp. 1055 y ss.; Augusto Duran Martínez, "La presunción de legitimidad del acto administrativo: un mito innecesario y pernicioso", Revista de Derecho, n. ${ }^{\circ} 2,2007$, pp. 119 y ss., y "Otra vez sobre la inexistente presunción de legitimidad del acto administrativo", en La Justicia Uruguaya, t. 139, 2009, pp. 53 y ss.; Graciela Ruocco, "Crisis de un paradigma: la presunción de legitimidad del acto administrativo", Estudios de Derecho Administrativo, n. ${ }^{\circ} 5$, 2012, pp. 783 y ss.; y MARIANO ARAMBERRI, "La presunción de legitimidad del acto administrativo", Anuario de Derecho Administrativo, t. XIV, 2007, pp. 11 y ss.

52 Véase una enumeración sistemática de las ocho principales diferencias entre el sistema de nulidades civiles y el sistema de nulidades administrativas en Agustín GordiLlo, Tratado de derecho administrativo, óp. cit., pp. XI-4 y ss.

53 Fernando Garrido Falla, Tratado de derecho administrativo, t. I, 11. a ed., Madrid: Tecnos, 1989 p. 415 .

54 Massimo Severo Giannini, Lezioni di Diritto Amministrativo, vol. 1, Milán: Giuffrè, 1950, p. 384.

55 Agustín Gordillo, Tratado de derecho administrativo, óp. cit., p. XI-4. 
3.3. RESPUESTA JURISPRUDENCIAL EN ASPECTOS ESPECÍFICOS RELACIONADOS CON LA NULIDAD CONTRACTUAL

La jurisprudencia uruguaya que se ha ocupado del tema lo ha hecho principalmente con respecto a la anulabilidad de los actos administrativos anteriores al contrato (recaídos en los procedimientos de selección del contratista) y los dictados con posterioridad (durante la ejecución contractual). Siguiendo el criterio expuesto al relevar los vicios que afectan los elementos contractuales, resulta ilustrativo traer a colación algunos fallos referidos a los mismos.

Respecto al elemento subjetivo, el Tribunal de lo Contencioso Administrativo se ha pronunciado tanto sobre la competencia de la Administración contratante como sobre las limitaciones del cocontratante ${ }^{56}$. Por un lado, en cuanto refiere vicio de incompetencia de la Administración contratante, ha dicho reiteradamente que es el más grave. Así, a título de ejemplo, la sentencia n. ${ }^{\circ}$ 587 de 16 de agosto de 2001 manifestó que "La violación de las normas sobe competencia determina la nulidad del respectivo acto administrativo. Eso obedece a que la competencia representa un requisito o elemento esencial del acto administrativo [...]. El vicio de incompetencia, como lo ha proclamado el Tribunal, es el más grave que inficiona de nulidad al acto administrativo" ${ }^{15}$.

En materia de inbabilidades del cocontratante, la sentencia n. ${ }^{\circ} 698$ de 20 de agosto de 2000 entendió que el alcance del numeral $1 .^{\circ}$ del artículo 43 [hoy, artículo 46] del TOCAF abarca no solamente a los funcionarios públicos que están vinculados por razones de dependencia sino también a aquellos que están vinculados por razones de dirección. A juicio del Tribunal, "Como directores, están impedidos de concurrir como oferentes en razón de la prohibición prevista en el numeral $1 .^{\circ}$ del artículo 43 [hoy, artículo 46] del TOCAF. La evidencia de la ilegalidad expresada fue puesta de manifiesto por la actitud de la propia empresa ya que, en la observación efectuada por el Tribunal de Cuentas al respecto (considerando $7 .^{\circ}$ de la resolución recaída en la sesión de 22 de enero de 1997) se resolvió por los accionistas la designación de un nuevo directorio de la sociedad con personas que no son funcionarios públicos. Pero el hecho de que la empresa haya sustituido los miembros del directorio con posterioridad a la observación del Tribunal de Cuentas, amén de corroborar la aceptación tácita de la existencia del impedimento, la sustitución luego de

56 Carlos E. Delpiazzo y Graciela Ruocco, Tratado jurisprudencial y doctrinario sobre actos y contratos de la Administración, t. I, Montevideo: La Ley Uruguay, 2013, p. 364.

57 Cfr. Héctor Giorgi, El contencioso administrativo de anulación, Montevideo: Biblioteca de publicaciones oficiales de la Facultad de Derecho y Ciencias Sociales de la Universidad de la República, 1958, p. 199; EnRiQue Sayagues Laso, Tratado de derecho administrativo, t. I, Montevideo: Barreiro y Ramos 1963, pp. 512-516 y 432-434; y Tribunal de lo Contenciosos Administrativo, sentencias n. ${ }^{\circ} 1267$ de 8 de diciembre de 1993, n. ${ }^{\circ} 373$ de 6 de setiembre de 1989 y n. $^{\circ} 462$ de 1998 . 
la apertura de las ofertas no enerva la ilegalidad porque [... ] la situación ilegal quedó consolidada al momento de la apertura de ofertas y cualquier modificación posterior atenta al principio de igualdad de los oferentes".

En cuanto al elemento objetivo, el Tribunal de lo Contencioso Administrativo ha entendido que la irrazonabilidad de la actuación administrativa mientras transcurre la vida del contrato hace anulable la volición respectiva. Al tenor de su sentencia n. ${ }^{\circ} 464$ de 4 de agosto de 2016, "la Administración puede acordar, durante la ejecución del contrato, la modificación del contrato que la vincula con su cocontratante. En estos casos, un nuevo acto contractual -expreso o implícito-sustituirá en lo pertinente las previsiones del anterior". Agrega que "en cuanto a la apreciación de la existencia o inexistencia en sí misma de los hechos y su valoración jurídica (legitimidad o ilegitimidad), la Administración no goza de ninguna discrecionalidad. Si los hechos operantes como supuesto normativo, o motivo del acto administrativo, no existen o no son como la Administración pretende, el acto estará viciado por inexistencia de los motivos. O si los hechos son como la Administración pretende, pero no caben en el supuesto (determinado o indeterminado) de la norma atributiva del poder de dictar el acto, este estará viciado por ilegitimidad de los motivos ${ }^{\prime \prime 15}$.

Con carácter general, la sentencia del Tribunal de lo Contencioso Administrativo n. ${ }^{\circ} 245$ de 2 de abril de 1997, haciendo aplicación al campo de la contratación administrativa de su jurisprudencia respecto al denominado principio de trascendencia en materia de nulidades, sostuvo que no son de recibo los agravios que refieren a "irregularidades de carácter secundario insusceptibles de configurar un vicio", sin perjuicio de reconocer que "en la teoría general de las nulidades juega el importante principio de legalidad o especificidad según el cual no existe nulidad sin norma habilitante (lo que, obviamente, no excluye las llamadas nulidades virtuales o implícitas, también de aplicación frecuente en derecho público por la notable incidencia de normas como las de los artículos 72, 332 y ccs. de la Constitución) $)^{\prime \prime 59}$.

Con referencia al elemento teleológico, la sentencia del Tribunal de lo Contencioso Administrativo n. ${ }^{\circ} 302$ de 26 de abril de 2000 se explaya en que "La juridicidad del acto requiere que el mismo armonice con el interés público concretado en la finalidad a que debe responder la emisión del acto. Se ha dicho con acierto que no existe discrecionalidad en cuanto a la finalidad del acto. No es concebible el ejercicio del poder discrecional para satisfacer fines ajenos a la norma -formal o material- aplicable en el caso, o para satisfacer

Juan Pablo Cajarville Peluffo, "Sobre actos administrativos", en Sobre derecho administrativo, t. II, Montevideo: FCU, 2008, pp. 31-32; en jurisprudencia, véanse Tribunal de lo Contencioso Administrativo, sentencias n. ${ }^{\circ} 416 / 2015$, n. ${ }^{\circ}$ 170/2012, n. ${ }^{\circ} 165 / 2013$, n. ${ }^{\circ}$ 246/2013 y n. ${ }^{\circ}$ 523/2014, entre otras.

59 Carlos E. Delpiazzo y Graciela Ruocco. Tratado jurisprudencial y doctrinario, t. II, óp. cit., pp. 1549 y ss. 
fines que, aún siendo de interés público, sean extraños a los que determina la competencia del respectivo agente de la Administración. Si así ocurriere, el acto administrativo hallaríase viciado de desviación de poder [...]. Se ha hecho especial hincapié por la doctrina especializada -en criterio que este Tribunal comparte- que el órgano jurisdiccional de control debe realizar todo el esfuerzo necesario para poner en claro la efectiva y verdadera finalidad del acto emitido ${ }^{60}$, pues si así no fuere, las garantías de la Administración solo consistirían en vanas palabras, siendo de recordar que las garantías individuales no surgen tanto de la letra de la ley, como de la aplicación efectiva de esta"61.

En lo que dice relación con el elemento formal, es donde se registra un desarrollo jurisprudencial más importante, que cubre diversos momentos ${ }^{62}$.

En cuanto a los vicios anteriores al acto de apertura, la sentencia del Tribunal de lo Contencioso Administrativo n. ${ }^{\circ} 152$ de 16 de abril de 2009 estimó "indudable que las modificaciones introducidas al pliego particular violentaron el principio de igualdad que ampara a todos los oferentes; principio de igualdad que contribuye a justificar el carácter obligatorio, de respeto irrestricto de las cláusulas establecidas en el pliego respectivo, pues si la Administración se apartara de ellas al juzgar las ofertas, los licitantes quedarían a merced de una arbitrariedad administrativa. Y en la especie resulta incontrovertible que una de las cláusulas del pliego particular fue modificada por la Administración unos días antes del acto de apertura de propuestas y posterior adjudicación, todo lo cual inclina al Tribunal a decretar la nulidad del acto administrativo impugnado".

En similares términos, la sentencia del Tribunal de lo Contencioso Administrativo n. ${ }^{\circ} 940$ de 11 de noviembre de 2010 afirmó: "Desde que la contratación administrativa debe fundarse en el principio de razonabilidad para cumplir con el fin público comprometido, lo que no impide que en determinadas circunstancias se encuentre en la necesidad de modificar los pliegos, ello solo puede ocurrir siempre que no importe un menoscabo a los principios de igualdad y libre concurrencia del procedimiento licitatorio: que esas modificaciones sean anteriores a la presentación de las ofertas; si ello opera con posterioridad, importa virtualmente un nuevo llamado a licitación sobre las bases de las nuevas condiciones establecidas. No se puede pasar por alto que fue la propia Administración que fijó las bases de la licitación, por lo que debía ajustar su conducta a lo establecido por ella misma".

60 Véase Carlos E. Delpiazzo, "Trascendencia práctica de los principios generales de Derecho en el control jurisdiccional de la discrecionalidad administrativa", Suplemento de Derecho Administrativo de Revista El Derecho, n. ${ }^{\circ} 14.522,2018$, pp. 1 y ss.

61 Carlos E. Delpiazzo y Graciela Ruocco. Tratado jurisprudencial y doctrinario..., t. I, óp. cit., pp. 68-69.

62 Ibíd., pp. 365-366. 
Con relación a los vicios del acto de apertura, la sentencia del Tribunal de lo Contencioso Administrativo n. ${ }^{\circ} 779$ de 6 de diciembre de 2001 postuló que "configura causal suficiente de nulidad la anomalía registrada en oportunidad de concretarse el acto de apertura de ofertas". Habiéndose concedido un plazo de 48 horas hábiles a uno y más extenso a otros comparecientes, entendió que "Este plazo de 7 días excede del previsto en el artículo 56 [hoy: artículo 65] del tOCAF ( 2 días según el inc. $5 .^{\circ}$ ) y, cotejado con el concedido a la ahora accionante, configura una clara violación del principio de igualdad consagrado en diversas disposiciones del tocaf [...]. Se asiste pues, a un tratamiento discriminatorio carente de toda justificación".

Una vez abiertas, la modificación de las ofertas por vía de aclaración es considerada causal de nulidad. Según la sentencia del Tribunal de lo Contencioso Administrativo n. ${ }^{\circ} 794$ de 19 de setiembre de 1994, entre otras (así, sentencia n. ${ }^{\circ} 714$ de $1 .{ }^{\circ}$ de octubre de 1997) se afecta el principio de igualdad de los licitantes "al admitirse una aclaración de la adjudicataria que de hecho modificó el resultado de la licitación, sin siquiera oírse a los demás licitantes".

Tratándose de la omisión de vista, ha entendido la sentencia del Tribunal de lo Contencioso Administrativo n. ${ }^{\circ} 1014$ de 9 de noviembre de 1998 que en los procedimientos de selección en que ella no está impuesta por el artículo 58 del TOCAF no se produce nulidad. Ello es así, entre otros fundamentos, porque la omisión de vista previa "debe ser influyente respecto del acto que se aduce inficionado, no configurando aquel extremo nulidad en forma automática. Porque no toda irregularidad vicia el acto, sino que solamente la afecta de tal forma aquella que lo inficiona pesando o influyendo, de manera decisiva, en el contenido del pronunciamiento de la Administración (sentencias n. ${ }^{\circ}$ 589/990, n. ${ }^{\circ} 599 / 990$, n. $^{\circ} 1068 / 992$ y n. $^{\circ} 122 / 997$, etc. $)^{\prime \prime}$.

Sobre los vicios del acto de adjudicación, la sentencia del Tribunal de lo Contencioso Administrativo n. ${ }^{\circ} 73$ de 13 de marzo de 2000, en línea con anteriores pronunciamientos de similar tenor, dijo: "El Tribunal destaca desde un pronunciamiento ya lejano que la discrecionalidad que tiene la Administración en la adjudicación de propuestas, deja de ser tal para transformarse en libertad incontrolable cuando se aparta de la propuesta aparente más favorable en base a una circunstancia de hecho que, siendo conocida desde antes de la convocatoria, no se hizo figurar en el pliego de condiciones [...] (sentencia n. $\left.{ }^{\circ} 178 / 972\right)^{\prime \prime}$.

A su vez, en la sentencia del Tribunal de lo Contencioso Administrativo n. ${ }^{\circ} 1014$ de 9 de noviembre de 1998, haciendo caudal del principio de trascendencia, señaló que "es de regla que las irregularidades de escasa o relativa trascendencia, que no influyen sobre la situación de igualdad de los proponentes y que carezcan de consecuencias en el resultado final del procedimiento, no vician el mismo (sentencia n. ${ }^{\circ}$ 358/987)". Agregó que: "En el caso, solo razones de orden formal, vinculadas con el otorgamiento de vista previa que el Tribunal no estima concurrentes, podrían haber provocado la nulidad del 
acto en causa. Empero, el cuerpo ha sostenido invariablemente que el acto de adjudicación no puede ser anulado en virtud de que, siendo su aniquilación una grave medida, ella no debe tener lugar sino cuando se comprueba una seria y trascendente trasgresión de los principios propios del procedimiento licitatorio y que, en esencia, son los que procuran, sobre la base de una igualdad objetiva de trato entre los diversos oferentes, la selección de la oferta que resulta más ventajosa para la Administración (sentencias n. ${ }^{\circ}$ 13, 168 y 350 de 1989, n. ${ }^{\circ} 86 / 986$, n. ${ }^{\circ} 47 / 991$, etc.)".

En la misma sentencia, la corporación reitera la jurisprudencia habitual con relación a los vicios en una preselección de ofertas, en el sentido de que cuando "el acto de adjudicación ha sido dictado omitiendo formas sustanciales legalmente impuestas o sus motivos no corresponden a los datos del caso o son espurios los móviles que han determinado el pronunciamiento de la Administración, entonces se habrá comprometido su licitud (sentencia n. ${ }^{\circ}$ 490/988). Solución que, naturalmente, cabe aplicar a un pronunciamiento en sede de precalificación, desde que no existiendo norma jurídica que lo regule en nuestro país, deben convocarse las disposiciones análogas de la misma materia licitatoria o de futura contratación administrativa".

También es considerado un grave vicio del acto de adjudicación, la ejecución del mismo antes de que quede firme y sin levantar el efecto suspensivo de la impugnación. En tal sentido, la citada sentencia del Tribunal de lo Contencioso Administrativo n. ${ }^{\circ} 779$ de 6 de diciembre de 2001 sostuvo que "la inexplicable premura con que se actuó (ejecución del acto antes de quedara firme) explica que no se haya dictado resolución levantando el efecto suspensivo del recurso de revocación... Esta circunstancia cierra el cúmulo de irregularidades de orden formal, adjetivo o ritual y de índole material o sustancial que conlleva inexorablemente el acogimiento de la pretensión anulatoria, ya que se verifica el extremo que el Tribunal invariablemente convoca para disponer soluciones anulatorias en casos de procesos licitatorios: violaciones graves de la normativa ocurrente y/o del o de los pliegos de condiciones que justifiquen la adopción de una medida extrema como es, sin duda alguna, la anulación de un acto de adjudicación de una licitación pública".

De igual modo, se reputó un grave vicio del acto de adjudicación por parte de la sentencia del Tribunal de lo Contencioso Administrativo n. ${ }^{\circ} 248$ de 8 de mayo de 2002 "cuando, como sucede en el caso, se admiten aclaraciones a algunos oferentes y no a todos, si de hecho con este procedimiento se modifica el resultado de la licitación (TCA, sentencia n. $\left.{ }^{\circ} 794 / 94\right)$.".

En cuanto a la trascendencia de la anulación de la adjudicación, tal como se señala en la sentencia del Tribunal de lo Contencioso Administrativo n. ${ }^{\circ} 472$ de 13 de agosto de 2001, es "constante la jurisprudencia del Tribunal en el sentido de que la nulidad del acto de adjudicación es siempre una grave medida que no debe tener lugar sino cuando se comprueba una seria y trascendente transgresión a los principios propios del procedimiento licitatorio que, y en esencia, son los 
que procuran, sobre la base de una igualdad objetiva de trato entre los oferentes, la selección de la oferta que resulte más ventajosa para la Administración (véase, entre otras, sentencias n. ${ }^{\circ}$ 13/89, 1353/92, 714/97, 1014/98 y 345/01) ) $63 .^{2}$

En similares términos, la sentencia del Tribunal de lo Contencioso Administrativo n. ${ }^{\circ} 27$ de 5 de febrero de 1992 dijo que "la adjudicación solo es anulable ante vicios graves de legalidad o flagrantes desviaciones de poder que tengan influencia incidente para la adopción de la selección, frente a la cual hay que adoptar una cauta actitud antes de decidir la anulación de tan grave y vastas consecuencias" ${ }^{\prime \prime 4}$.

Una cuestión de sensible interés que plantea la anulación de los actos precontractuales y singularmente el acto de adjudicación es la de sus efectos sobre el contrato en atención al reconocimiento legislativo en nuestro país de la doctrina de los actos separables en el artículo 23.b del ya citado Decreto Ley n. ${ }^{\circ} 15.524^{[65]}$.

La tesis afirmativa postula que, si el acto separable es soporte del contrato, no puede invalidarse aquel y subsistir vigente al contrato. Contrariamente, la tesis negativa sostiene que el recurrente no ataca el contrato, sino que ataca el acto individualizado separable, preexistente y, por lo tanto, deja subsistente el vínculo contractual. Sobre el particular, es valor aceptado que "no son recurribles administrativamente los contratos administrativos en sentido estricto, aunque sí lo son por previsión expresa, los llamados actos separables de los contratos ${ }^{\prime \prime 6}$. Asimismo, se ha enseñado que "el juzgamiento de la validez de los contratos, de la misma manera que el juzgamiento de los hechos, no entra -en virtud de no hallarnos ante actos administrativos- en la competencia de la jurisdicción anulatoria" ${ }^{167}$.

Más categóricamente, se ha postulado que "En cuanto a la resolución en materia de contratos, debemos observar que si hemos considerado separables los actos que constituyen el procedimiento administrativo, no es posible que su anulación influya en el contrato porque para que ello ocurriese sería necesario llegar a una solución absurda cual sería la de admitir que este acto separable se incorpora al contrato una vez realizado, lo que técnicamente sería imposible. De ahí entonces, consideramos que la anulación de un acto separable no trae aparejada forzosamente la anulación del acto celebrado"68. De forma coincidente, teniendo en cuenta desde el punto de vista práctico la duración

Carlos E. Delpiazzo y Graciela Ruocco, Tratado jurisprudencial y doctrinario..., óp. cit., p. 277.

65 Carlos E. Delpiazzo, Contratación administrativa, 2. a ed., óp. cit., p. 343.

66 Juan Pablo Cajarville Peluffo, Recursos administrativos, 4. ${ }^{\text {a }}$ ed., Montevideo: F.C.U., 2008 p. 117; Felipe Rotondo Tornaria, Manual de derecho administrativo, 10. ${ }^{a}$ ed., Montevideo: Del Foro, 2017, p. 412; y Augusto Duran MartíneZ, Contencioso administrativo, 2. a ed. Montevideo: F.C.U., 2015, p. 40.

67 HéCTOR GIORGI, El contencioso administrativo de anulación, óp. cit., p. 54.

68 Manuel María Diez, Derecho administrativo, tomo III, Buenos Aires: Plus Ultra, 1979, p. 151. 
promedio de los procesos contencioso administrativos de anulación, cabe coincidir con la opinión de que "Si el contrato se ha ejecutado o está en vías de ejecución, la solución que parece inevitable es la de indemnizar daños y perjuicios al licitador que logra la anulación del acto viciado, pues por fuerza de las circunstancias el contrato ha quedado en una zona inalcanzable" ${ }^{\prime \prime 69}$.

\subsection{Respuesta JURISPRUdENCIAL EN ASPECTOS GENERALES RELACIONADOS CON LA NULIDAD CONTRACTUAL}

Sin perjuicio de cuanto viene de decirse, cabe hacer referencia a pronunciamientos de la justicia en los cuales se ha hecho aplicación de principios generales, en algunos casos acudiendo directamente a ellos y en otros invocando normas contenidas en el Código Civil, en el entendido de que ellas recogen principios generales aplicables a todo contrato y no exclusivamente referidos a los contratos civiles.

En el primer supuesto, la jurisprudencia ha acudido reiteradamente a la invocación directa de diversos principios generales ${ }^{70}$. Es posible mencionar la sentencia del Tribunal de Apelaciones en lo Civil de $1 .^{\circ}$ Turno n. ${ }^{\circ} 34$ de 22 de marzo de 2006, en la cual se enfatiza en la trascendencia jurídica y práctica de los principios generales de derecho ante la ausencia de una normativa sistemática en materia de contratación administrativa en nuestro ordenamiento ${ }^{71}$. Múltiples

69 Roberto Dromi, Licitación pública. Buenos Aires: E.C.A., 1995, p. 176.

70 Carlos E. Delpiazzo, "Eficacia aplicativa de los principios generales de derecho en la contratación administrativa", Anuario de Derecho Administrativo, t. XIII, 2006, pp. 65 y ss.; y Carlos E. Delpiazzo y Graciela Ruocco, Tratado jurisprudencial y doctrinario.... t. II, sobre óp. cit., pp. 1109 y ss.

71 Dice el fallo que: "Señala la doctrina que en nuestro país -a diferencia de lo que ocurre en otros lugares del mundo- no existe una normativa legal orientada y sistematizada para regular la contratación administrativa y solo tenemos un conjunto de disposiciones que regulan el procedimiento administrativo de licitación y múltiples normas dispersas referidas a diversos contratos posibles y a algunos aspectos de ellos (C. Delpiazzo, Normas y principios de la contratación administrativa, 2002, p. 9). Según dicho autor, la mentada ausencia de normas legales específicas obliga a enfatizar la importancia de principios y disposiciones que regulan el género contractual y, en particular, la eficacia vinculante del contrato como regla de derecho para ambas partes y especialmente recordar el principio contenido en el artículo 1291 del Código Civil (C. Delpiazzo, Contratación administrativa, 1999, p. 242). De modo que es pacíficamente aceptado que, sin ignorar peculiaridades de la contratación administrativa, para resolver los problemas que puedan plantearse en la ejecución contractual es posible y necesario acudir a los principios y reglas que regulan

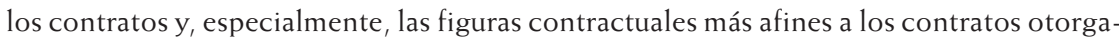
dos en casa caso por la Administración. En esta línea, resultan particularmente relevantes para resolver la cuestión planteada en este proceso, tanto el principio de buena fe, que exige colaboración de ambas partes en la ejecución de las obligaciones recíprocamente asumidas, como dada su manifiesta analogía con la contratación en examen, las normas que disciplinan el arrendamiento de obra (Código Civil, artículos 1831 y ss.)". CARLOs E. 
son los fallos que hacen aplicación específica de algunos principios en concreto para resolver distintos casos en materia contractual ${ }^{72}$.

Haciendo caudal del principio de flexibilidad, la sentencia del Tribunal de lo Contencioso Administrativo n. ${ }^{\circ} 660$ de 12 de mayo de 1999 señaló que "La flexibilidad supone un margen amplio para la decisión por parte de los responsables de las compras del Estado, en cuanto a la exigencia de requisitos y cuestiones de detalle, que no sean esenciales o fundamentales y que permitan solucionar problemas prácticos en función de los cuales muchas veces se anularon licitaciones o se declararon desiertas o incluso se contrató con quien no ofreció la mejor ventaja comparativa".

Apreciando la trascendencia del principio de publicidad respecto a los pliegos de condiciones, dice la sentencia del Tribunal de lo Contencioso Administrativo n. ${ }^{\circ} 256$ de 26 de junio de 2008: "antes de la publicidad -requerida normativamente- los pliegos no operan efectos jurídicos en la esfera de los particulares interesados, por lo que permanecen como actos internos de la Administración, pero una vez que han cobrado publicidad, los pliegos asumen una condición normativa o reglamentaria plena, hasta el momento de la presentación de las ofertas (y como tales pueden ser derogados, sustituidos o modificados sin mengua del principio de igualdad, que obligará a dar publicidad también de dichas derogaciones, sustituciones y modificaciones)". Asimismo, la igualdad de los oferentes como manifestación concreta del principio de igualdad ha tenido amplia recepción jurisprudencial. En tal sentido, las sentencias del Tribunal de lo Contencioso Administrativo n. ${ }^{\circ} 68$ de 24 de febrero de 1999 y n. ${ }^{\circ} 940$ de 11 de noviembre de 2010, entre muchas otras de similar tenor, han entendido que "la alteración de las propuestas o violaciones de los pliegos de condiciones en cuanto implican una lesión efectiva del tratamiento igualitario de los licitantes invalidan el acto de adjudicación".

Respecto al principio de concurrencia, reiteradamente ha sido considerado como cardinal en la licitación pública. Tal es el caso de la sentencia del Juzgado Letrado de Primera Instancia de lo Contencioso Administrativo de 2..$^{\circ}$ Turno n. ${ }^{\circ} 61$ de 15 de agosto de 2003, a cuyo tenor "La libre concurrencia y la igualdad entre los oferentes son los principios jurídicos esenciales de la licitación. El primero afianza la posibilidad de oposición entre los interesados en la futura contratación".

El principio de razonabilidad también ha sido ampliamente invocado por la jurisprudencia. Según la sentencia del Tribunal de lo Contencioso Administrativo n. ${ }^{\circ} 205$ de 15 de mayo de 1989, "la jurisprudencia debe siempre controlar si las potestades discrecionales se ejercieron razonablemente, pues el ámbito de libertad de la Administración no autoriza un ejercicio arbitrario de sus

Delpiazzo y Graciela Ruocco, Tratado jurisprudencial y doctrinario..., t. II, sobre óp. cit., pp. 1095 y ss. 
atribuciones". En similar sentido, la sentencia del mismo Tribunal de lo Contencioso Administrativo n. ${ }^{\circ} 98$ de 8 de marzo de 1999 entendió que "Cuando la razonabilidad se pierde, el acto se convierte en arbitrario y, por ende, en anulable [... ya que] arbitrario es lo irrazonable o injusto, por oposición a lo razonable, lo justo, proporcionado o equitativo. La arbitrariedad como concepto, constituye una distorsión del proceso, del juicio de razón que puede incidir sobre los distintos elementos del acto administrativo. La arbitrariedad se da cuando existe un desajuste en el proceso del juicio de razón entre sus elementos (prueba-norma-decisión)".

Con relación a los principios de ausencia de ritualismo y de materialidad, ha dicho la sentencia del Tribunal de lo Contencioso Administrativo n. ${ }^{\circ} 310$ de 7 de abril de 1997 que los mismos "implican que la Administración y el procedimiento no deben verse obligados a seguir cánones estrictos de trámite, siempre que ello no vaya en mengua de los derechos del administrado".

Igualmente, el principio de veracidad ha sido invocado reiteradamente por la jurisprudencia, asociado al principio de realidad y como un límite a los desbordes de poder en caso de indefensión del administrado. Tal es el caso de las sentencias del Tribunal de lo Contencioso Administrativo n. ${ }^{\circ} 426$ de 22 de agosto de 2007 y n. $^{\circ} 235$ de 17 de junio de 2008.

Asimismo, respecto al principio de buena fe en el ámbito de la contratación pública, la sentencia de la Suprema Corte de Justicia n. ${ }^{\circ} 115$ de 30 de julio de 2007, en jurisprudencia consolidada por otros fallos coincidentes, ha entendido que, por tratarse de una regla de comportamiento, debe ser encarado como un principio general de derecho, llamado a cumplir diversas funciones, entre las que se destacan la integradora y correctiva del contrato. Y por su intermedio se corrigen en bien de las estipulaciones contractuales que no se ajusten a ella, aplicándose a la Administración incluso en la etapa de tratativas. A juicio de la corporación, la regla del artículo 1291 del Código Civil es aplicación concreta de una regla más amplia, de vastos alcances, que encuentra su fundamento en valoraciones que provienen del orden ético social, exigencia de una conducta leal, honesta, escrupulosa, incluso solidaria, con verdadera actitud de cooperación, fiel a la palabra empeñada.

En el segundo de los supuestos indicados más arriba, es decir, en los casos en que se invocan disposiciones concretas del Código Civil, cabe referir, a vía de ejemplo, a casos de responsabilidad precontractual y contractual, así como acerca de las pautas para la interpretación de los contratos públicos en orden a la eventual anulabilidad total o parcial de los mismos.

Cabe aludir a casos relativos a responsabilidad precontractual y contractual ${ }^{73}$. Con respecto a la responsabilidad precontractual pública, la misma ha sido analizada p. 372 . 
por la sentencia del Tribunal de Apelaciones en lo Civil de 2..$^{\circ}$ Turno n. ${ }^{\circ} 574$ de 17 de agosto de 2011, en la que se señala que "si se entendiera que, luego de notificada la adjudicación, se continuaba en la etapa precontractual por no haberse otorgado el contrato escrito, la Administración debería igualmente responder por los perjuicios integrales causados a la adjudicataria si mediara desistimiento infundado, en tanto el administrado será titular de un derecho subjetivo a la contratación (cf. Delpiazzo, "Contratación administrativa", p. 193 y, en sentido similar, sentencia de la Corte n. $\left.{ }^{\circ} 899 / 94\right)^{\prime \prime 74}$.

Acerca del método de interpretación de los contratos públicos, han recaído pronunciamientos de los máximos órganos de expresión de la función jurisdiccional en nuestro país haciendo caudal de disposiciones del Código Civil como pautas generales al respecto ${ }^{75}$. Según la sentencia de la Suprema Corte de Justicia n. ${ }^{\circ} 129$ de 29 de mayo de 2009, "la interpretación de las disposiciones contractuales es questio juris y, como tal, pasible de ser revisada en casación. En efecto, las cláusulas que integran los contratos son normas jurídicas en la medida que conforme a la regla que consagra el artículo 1291 -principio de asimilación del contrato a la ley-constituyen normas que vinculan a las partes

74 A su vez, la sentencia del Juzgado Letrado de Primera Instancia en lo Civil de 18 Turno n. ${ }^{\circ}$ 28 de 26 de abril de 2010, en fallo confirmado por el Superior, postuló que "La responsabilidad contractual pública es la más trascendental de las garantías jurídicas del administrado que participa en la gestión administrativa contractual, frente a las lesiones que pueda sufrir en su patrimonio como consecuencia del comportamiento antijurídico de la Administración en la ejecución de sus obligaciones". Agrega que la actitud administrativa unilateral que impide la ejecución del contrato "genera responsabilidad puesto que de acuerdo a lo que establece el artículo 1253 del Código Civil, el cumplimiento de los contratos no puede dejarse al libre arbitrio de uno de los contrayentes [...]. Esta voluntad unilateral de la Administración demandada de negar o de imposibilitar la ejecución del contrato la hace incurrir en responsabilidad". Seguidamente, en cuanto a cuantificación de dicho daño, recuerda la sentencia que, aún quienes admiten la rescisión unilateral de los contratos administrativos atendiendo a razones de interés público, coinciden en que "esta potestad tiene como contrapartida que en ese caso debe resarcirse a los contratistas particulares por los perjuicios que ocasione la intempestiva ruptura del contrato administrativo, sin perjuicio de los debidos controles. En el mismo sentido, el Dr. Jorge Gamarra, Tratado de derecho civil uruguayo, tomo I, pp. $28-283$, y ADCu, tomo XXXVI, donde se sostiene que el derecho potestativo del comitente de rescindir el contrato supone el fin del contrato mismo ya que anula la relación jurídica generando la obligación de indemnizar todos los gastos y todo lo que pudo ganar con la obra, fundando ello en el artículo 1847 del C.C. En conclusión, dentro de los rubros a indemnizar [también en caso de incumplimiento] se encuentran todos los gastos y trabajos hechos siendo este el daño emergente y además la privación de las ganancias de todo lo que hubiera podido ganar en la misma obra (artículos 1345 y 1847 C.C.). Pero este régimen indemnizatorio del artículo 1847 C.C. tiene un límite autoimpuesto por la misma norma en cuanto deben de estar directamente relacionados con la obra en sî".

75 Carlos E. Delpiazzo. "Sobre interpretación de los contratos públicos", en Carlos E. Delpiazzo y José Luis Echevarria Petit (coords.). Cuaderno 1 de Contratación Pública. Montevideo: U.M., 2017, p. 225 y ss. 
como la ley misma. En consecuencia, configura causal de casación (artículo 270 CGP) el apartamiento del Oficio de los preceptos lógico jurídicos que tienen por finalidad constatar el significado de las voluntades de los contratantes, imponiendo acudir a los elementos textuales y extratextuales relevantes como necesario antecedente de la determinación de los efectos jurídicos del negocio (cfr. sentencias n. ${ }^{\circ}$ 54/1995, 14/2001, 237/2002 y 178/2003 ; Gamarra, Tratado..., tomo XVIII, 1980, pp. 198-199, y Andrés Mariño López, "La interpretación del contrato en el derecho uruguayo", en A.D.C.U., tomo XXVIII, p. 602)". Asimismo, ha dicho la Corte en su sentencia n. ${ }^{\circ} 115$ de 30 de julio de 2007 que cuando el documento contractual ha sido confeccionado por la parte estatal, "este extremo torna aplicable la consecuencia normativa prevista en el artículo 1304 del C. Civil, según el cual, si la cláusula ambigua ha sido extendida o dictada por una de las partes, se interpretará en su contra, siempre que tal condición provenga de su falta de explicitación (cf. Gamarra, óp. cit., p. 245; Rodríguez Russo, La interpretación de los contratos, p. 231 y nota al pie) $)^{1176}$. Interesa destacar que la misma sentencia se pronuncia en el sentido de que "El artículo $1301 \mathrm{del}$ C. Civil admite tomar en cuenta los hechos posteriores al acuerdo debatido, ejecutados por las partes, para la reconstrucción de sus comunes intenciones, pero nada impide que también se acuda a las circunstancias fácticas anteriores, orientadas en el mismo sentido (cf. Gamarra, Tratado..., óp. cit., tomo XVIII, p. 223) [...]. La posición contraria supondría desatender la pauta interpretativa prevista en el artículo 1301 del C. Civil, sin tener en cuenta que el conjunto de actos realizados por las partes en ejecución del tipo contractual posee un indudable valor como medio hermenéutico, en razón de lo que podría denominarse un principio de coherencia y de continuidad en la voluntad contractual, en la fase de conclusión y en la fase de ejecución del contrato (cf. Diez Picazo, cita de Rodríguez Russo, óp. cit., p. 201)".

En sentido similar, la sentencia del Tribunal de lo Contencioso Administrativo n. ${ }^{\circ} 126$ de 13 de febrero de 2015 ha acudido a similares criterios para interpretar y categorizar a los contratos públicos: "la interpretación establece cuál es el sentido a atribuir al texto contractual y tiene como resultado la determinación de las normas generadas por el mismo. La calificación establece la naturaleza del contrato (categorización) y que normas jurídicas han de aplicársele. La calificación determina el tipo de contrato de que se trata y de ello se infiere cuáles normas jurídicas generales lo regulan (Mariño López, "La interpretación judicial del contrato en el derecho uruguayo. Estudio del sistema de reglas hermenéuticas del Código Civil", en ADCU, tomo XXVIII, Montevideo: F.C.U., 1998, p. 615). La actividad intelectiva reseñada obviamente no resulta privativa

76 Carlos E. Delpiazzo, "Sobre interpretación de los contratos públicos", en Carlos E. Delpiazzo y José Luis Echevarría Petit (coords.), Cuaderno 1 de Contratación Pública, Montevideo: U.M., 2017, p. 233. 
de los contratos civiles, sino también de aquellos contratos administrativos en los que los sujetos pactantes (o alguno de ellos) son órganos estatales y su actividad se desarrolla (en todo o en parte) por disposiciones exorbitantes propias del derecho público. Pese a ello, la labor interpretativa del órgano jurisdiccional competente es sustancialmente idéntica y sus consecuencias ${ }^{1177}$.

\section{CONCLUSIONES}

Para terminar, consideramos que es posible pensar en la construcción de una teoría de las nulidades de derecho público -entre ellas, las contractuales- a partir de los principios generales, teniendo en cuenta que ellos no están exiliados de los códigos civiles. En efecto, sin que este sea el lugar para examinar

77 Carlos E. Delpiazzo, "Sobre interpretación de los contratos públicos", óp. cit., pp. 183 y ss., y 234. Más explícitamente, ha dicho el Tribunal en su sentencia n. ${ }^{\circ} 390$ de 28 de junio de 2016 que "A la hora de interpretar la cláusula contractual en torno a la que gira el diferendo entre las partes, corresponde tener en cuenta las reglas de interpretación de los contratos que resultan aplicables. Como enseña Cajarville, la interpretación de los contratos con la Administración debe hacerse también empleando las reglas contenidas en el Código Civil, por lo que las disposiciones de ese cuerpo normativo resultan plenamente aplicables. El principio básico de interpretación, aplicable a los contratos con las entidades estatales, impone al intérprete buscar la común intención de las partes antes que el sentido literal de los términos; por otra parte, los hechos de las partes tanto anteriores como posteriores al contrato -que tengan relación con lo que se discute- servirán para explicar la común intención de las partes al tiempo de su celebración (Cf. Cajarville Peluffo, "Sobre contratación de la Administración", en Sobre derecho administrativo, t. II, Montevideo: FCU, 2012, pp. 359-361). En la especie, el Tribunal considera que corresponde tener especialmente en cuenta lo establecido en el artículo 1298 del Código Civil, que es la regla fundamental en el proceso para determinar el significado concreto de la norma privada objeto de interpretación. El referido precepto ordena atender a la intención común de las partes, por lo que el intérprete debe atender a todos los elementos, textuales y extratextuales. Como enseña la doctrina -más allá de matices- un contrato no se interpreta solamente por sus elementos textuales sino que deben tenerse en cuenta un complejo de elementos textuales y extratextuales, cuyo análisis global es el que permite reconstruir la voluntad común de los contratantes. La interpretación contractual tiene por finalidad constatar el significado de la voluntad de los contratantes, saber lo que ellos quisieron; comprobando lo que las partes acordaron se sabrá cuáles son los efectos jurídicos (esto es, la regulación que rige a los autores del negocio. La interpretación judicial del contrato es una actividad reglada por una serie de preceptos que fijan los criterios que deben presidir la labor, y de estos métodos o criterios lógicos jurídicos el magistrado no puede apartarse. El objetivo será el de determinar la intención común de las partes planteada en el contrato, para lo cual se debe partir del texto, pero deben tenerse en consideración los aspectos extratextuales indicativos de la común intención de los contratantes, resultando en tal sentido especialmente relevante la valoración de los hechos y los actos posteriores al contrato, que tengan relación con lo que se discute, los que servirán para explicar la común intención de los contratantes artículo 1301 del Código Civil". 
las relaciones del derecho administrativo con el derecho civil ${ }^{78}$, debe tenerse presente que los códigos civiles explicitan en muchos casos -también en materia contractual- principios generales que, por ende, pueden ser aplicables a todas las ramas del ordenamiento jurídico porque son el sustento estructural del derecho todo ${ }^{79}$. Bajo esta perspectiva, la anulabilidad por vicios es predicable de los contratos públicos ya que la invalidez de los mismos puede alcanzarse mediante la aplicación de los principios generales (soportes del derecho todo) sin que a ello se oponga el recurso a las reglas del Código Civil, en cuanto estas guarden congruencia con la naturaleza, fines y garantías propios del derecho administrativo, en la medida que las categorías relativas a la invalidez, oriundas del derecho privado, recogen en realidad principios generales del derecho.

No obstante lo dicho, somos conscientes de las dificultades del tema y en modo alguno creemos tener la respuesta a todas las preguntas que los operadores del derecho se plantean. Pero tenemos la firme convicción de que si avanzamos en el camino de la construcción de una teoría general de las nulidades habremos dado un paso significativo en el fortalecimiento de un Estado de derecho verdadero. Sin que ello signifique una excusa, vale la pena tener presente que Enrique Sayagues Laso, el más grande de los administrativistas uruguayos, prefirió hablar de irregularidades respecto a los actos administrativos para sortear el abordaje de la compleja cuestión de las nulidades, reconociendo expresamente que "constituye uno de los capítulos más difíciles del derecho público" ${ }^{1180}$, y respecto de los contratos el maestro de todos, ni siquiera analizó el tema, limitándose a señalar, en sede de extinción de los mismos, que "Igual que los actos administrativos, los contratos pueden adolecer de irregularidades que afecten su validez", agregando -en posición seguida actualmente por calificada doctrina argentina a partir de su ley de procedimientos administrativosque "Las reglas expuestas al estudiar los actos administrativos son, en general, aplicables a los contratos, tomando debida cuenta de las particularidades de estos en cuanto a sus elementos esenciales ${ }^{\prime \prime}$.

78 Alejandro Vergara Blanco, El derecho administrativo como sistema autónomo. El mito del Código Civil como derecho común, Santiago: Legal Publishing Chile, 2010, pp. 67 y ss.

79 Carlos E. Delpiazzo, "Reconocimiento de los principios generales de derecho en el derecho administrativo uruguayo", en Jaime Arancibia y José Ignacio Martínez (coords.), La primacía de la persona. Estudios en bomenaje al Prof. Eduardo Soto Kloss, Santiago: Legal Publishing, 2009, p. 229 y ss.; "Recepción de los principios generales de derecho por el derecho positivo uruguayo", en AA. VV., Los principios en el derecho administrativo iberoamericano. Actas del VII Foro Iberoamericano de Derecho Administrativo, La Coruña: Netbiblo, 2008, pp. 607 y ss.; y Mariano R. Brito, Juan Pablo Cajarville Peluffo, Carlos E. Delpiazzo y Augusto Duran MARTíNEZ, Los principios en el derecho administrativo uruguayo, Montevideo: A.M.F., 2009, pp. 31 y ss.

80 EnRIQue Sayagues Laso, Tratado de derecho administrativo, óp. cit., p. 498.

81 Ibíd., pp. 574-575. 


\section{BIBLIOGRAFÍA}

Aramberri, Mariano. "La presunción de legitimidad del acto administrativo". Anuario de Derecho Administrativo, t. XIV, 2007.

Baca Oneto, Víctor Sebastián. La invalidez de los contratos públicos. Navarra: Thomson Civitas, 2006.

Bacellar Filho, Romeu Felipe. Direito Administrativo e o novo Código Civil. Belo Horizonte: Editora Forum, 2007.

Benavides, José Luis y Moreno Cruz, Pablo (eds.). La contratación pública en América Latina. Bogotá: Universidad Externado de Colombia, 2016.

Botassi, Carlos A. "Invalidez del contrato administrativo". En Juan Carlos Cassagne y Enrique Rivero Isern (dirs.), La contratación pública, t. 2. Buenos Aires: Hammurabi, 2006.

Brito, Mariano R., Juan Pablo Cajarville Peluffo, Carlos E. Delpiazzo y AugusTO DURAN MARTínEZ, Los principios en el derecho administrativo uruguayo. Montevideo: A.M.F., 2009.

Cajarville Peluffo, Juan Pablo. "Extinción de los contratos de la Administración", en Instituto Uruguayo de Derecho Administrativo. Contratación administrativa. Curso de graduados 1988. Montevideo: FCU, 1989.

Cajarville Peluffo, Juan Pablo. "Sobre actos administrativos". En Sobre derecho administrativo, t. II. Montevideo: FCU, 2008.

Cajarville Peluffo, Juan Pablo. Recursos administrativos, 4, a ed. Montevideo: FCU, 2008.

Cajarville Peluffo, Juan Pablo. Sobre derecho administrativo, t. II, 3. a ed. Montevideo: F.C.U., 2012.

Cassagne, Juan Carlos. Ley Nacional de Procedimientos Administrativos. Buenos Aires: La Ley, 2009.

Cassinelli Muñoz, Horacio. "Competencia del Poder Judicial para conocer la validez de un acto administrativo como premisa del fallo". Revista Derecho, Jurisprudencia y Administración, t. 71, 1971.

Cassinelli Muñoz, Horacio. Derecho constitucional y administrativo. Montevideo: La Ley Uruguay, 2010.

Cassinelli Muñoz, Horacio. "Oposición superviniente: ¿derogación o inconstitucionalidad?". Revista Derecho, Jurisprudencia y Administración, t. 55, 1958. 
Comadira, Julio Rodolfo. Procedimientos administrativos, t. I. Buenos Aires: La Ley, 2002.

Couture, Eduardo J. Vocabulario jurídico. Buenos Aires: Depalma, 1976.

Delpiazzo, Carlos E. "A propósito del tercer tocaf". La Justicia Uruguaya, t. 146, 2012.

Delpiazzo, Carlos E. "Acerca de los sujetos en los contratos públicos". Estudios de Derecho Administrativo, n. ${ }^{\circ} 8,2013$.

Delpiazzo, Carlos E. "Caracteres del acto administrativo". En Visión actual del acto administrativo. XI Foro Iberoamericano de Derecho Administrativo. Santo Domingo: FinjusAdda, 2012.

Delpiazzo, Carlos E. "Eficacia aplicativa de los principios generales de Derecho en la contratación administrativa". Anuario de Derecho Administrativo, t. XIII, 2006.

Delpiazzo, Carlos E. "Génesis y evolución del tocaf". En Carlos E. Delpiazzo (coor.), Comentarios al TOCAF sobre la Hacienda Pública. Montevideo: U.M., 2012.

Delpiazzo, Carlos E. "Notas acerca de las nulidades de los actos administrativos". Revista de Derecho Público, n. ${ }^{\circ} 42,2012$.

Delpiazzo, Carlos E. "Régimen contencioso administrativo uruguayo". En Jaime Rodríguez Arana y Marta García Pérez (coords.), La jurisdicción contencioso administrativa en Iberoamérica. Caracas: Editorial Jurídica Venezolana, 2014.

Delpiazzo, Carlos E. "Revocación del acto administrativo por razones de legitimidad y derechos adquiridos". En AA. VV., Seguridad jurídica y derecho administrativo. Montevideo: F.C.U., 2011.

Delpiazzo, Carlos E. "Sobre interpretación de los contratos públicos". En Carlos E. Delpiazzo y José Luis Echevarría Petit (coords.), Cuaderno 1 de Contratación Pública. Montevideo: U.M., 2017.

Delpiazzo, Carlos E. Contratación administrativa. Montevideo: Editorial Universidad Montevideo, 2005.

Delpiazzo, Carlos E. Derecho administrativo general, vol. 2. Montevideo: A.M.F., 2013.

Delpiazzo, Carlos E. Derecho administrativo general, vol. 1, 2. ${ }^{\text {a }}$ ed. Montevideo: A.M.F. 2015

Delpiazzo, Carlos E. Estudios sobre la responsabilidad de la Administración. Montevideo: U.M, 2009.

Delpiazzo, Carlos E. Manual de contratación administrativa, t. I, 3. ${ }^{\text {a }}$ ed. Montevideo: Editorial Universidad Montevideo, 1997. 
Delpiazzo, Carlos E. y Graciela Ruocco. Tratado jurisprudencial y doctrinario sobre actos y contratos de la Administración. Montevideo: La Ley Uruguay, 2013.

Diez, Manuel María. Derecho administrativo, tomo III. Buenos Aires: Plus Ultra, 1979.

Dromi, Roberto. Licitación pública. Buenos Aires: E.C.A., 1995.

Duran Martínez, Augusto. "Desviación, abuso y exceso de poder". En Estudios de Derecho Administrativo. Parte general. Montevideo: ADM, 1999.

Duran Martínez, Augusto. "Ejecución de los contratos administrativos. Eficacia vinculante. El contrato como regla de derecho. Mutabilidad del contrato". En Instituto Uruguayo de Derecho Administrativo, Contratación administrativa. Curso de graduados 1988. Montevideo: FCU, 1989.

Duran Martínez, Augusto. "La presunción de legitimidad del acto administrativo: un mito innecesario y pernicioso". Revista de Derecho, n. ${ }^{\circ}$ 2, 2007.

Duran Martínez, Augusto. "Otra vez sobre la inexistente presunción de legitimidad del acto administrativo". La Justicia Uruguaya, t. 139, 2009.

Duran Martínez, Augusto. Contencioso administrativo, 2. ${ }^{a}$ ed. Montevideo: FCU, 2015.

Flores, Rubén. "¿Es competencia exclusiva del Tribunal de lo Contencioso Administrativo el control jurisdiccional de los actos administrativos?". Anuario de Derecho Administrativo, t. VI, 1998.

Gamarra, Jorge. Estudios sobre obligaciones. Montevideo: Medina, 1956.

Gamarra, Jorge. Tratado de derecho civil uruguayo, t. XVI. Montevideo: Fundación de Cultura Universitaria, 1974.

Garrido Falla, Fernando. Tratado de derecho administrativo, t. I, 11. a ed. Madrid: Tecnos, 1989 .

Gelsi Bidart, Adolfo. De las nulidades en los actos procesales. Montevideo: A.M.F., 1981.

Giannini, Massimo Severo. Lezioni di Diritto Amministrativo, vol. 1. Milán: Giuffrè, 1950.

Giorgi, HéCtor. El contencioso administrativo de anulación. Montevideo: Biblioteca de publicaciones oficiales de la Facultad de Derecho y Ciencias Sociales de la Universidad de la República, 1958.

Gordillo, Agustín. Tratado de derecho administrativo, t. 3, 4. ${ }^{a}$ ed. Buenos Aires: Fundación de Derecho Administrativo, 1999.

Jinesta Lobo, ERnesto (coord.). El régimen de los contratos públicos. Bogotá: Temis, 2019. 
Mairal, Héctor A. Licitación pública. Protección jurídica de los oferentes. Buenos Aires: Depalma, 1975.

MARiÑo LóPEZ, ANDRÉS. "La interpretación del contrato en el derecho uruguayo". $A D C U$, t. XXVIII, 1997.

Moreno Molina, José Antonio y Andry Mantilla Correa. Contratos públicos en España, Portugal y América Latina. Madrid: Difusión Jurídica, 2008.

Peirano Facio, Jorge. Curso de obligaciones, t. vi. Montevideo: F.C.U., 1957.

Pisano, Juan A. y Rubén Flores. "¿Es siempre admisible el control de los actos administrativos por el Poder Judicial?". Anuario de Derecho Administrativo, t. VII, 1999.

Prat, Julio A. De la desviación de poder. Montevideo: Facultad de Derecho y Ciencias Sociales - Biblioteca de Publicaciones Oficiales, 1957.

Prat, Julio A. Derecho administrativo, t. III, vol. 2. Montevideo: Acali, 1980.

Prat, Julio A. La desviación de poder. Montevideo: A.M.F., 1976.

Prat, Agustín y Gustavo Fischer. "Desaplicación en vía jurisdiccional de un acto administrativo ilegal por el cual se concedió el registro de una marca en violación de normas prohibitivas". Revista de Derecho Público, n. ${ }^{\circ}$ 2-3, 1993.

Real, Alberto Ramón. "Desviación de poder". Estudios de Derecho Administrativo, t. II, 1967.

Rodríguez Arana, Jaime y Carlos E. Delpiazzo (eds.). Bases y retos de la contratación pública en el escenario global. Actas del XVI Foro Iberoamericano de Derecho Administrativo. Caracas: Editorial Jurídica Venezolana International, 2017.

Rodríguez Arana, Jaime, Miguel A Sendín y Jorge Danos. Contratación pública. Arequipa: Adrus, 2013.

Rotondo Tornaria, Felipe. Manual de derecho administrativo, 10. ${ }^{a}$ ed., Montevideo: Del Foro, 2017.

Ruocco, Graciela. "Crisis de un paradigma: la presunción de legitimidad del acto administrativo". Estudios de Derecho Administrativo, n. ${ }^{\circ}$ 5, 2012.

Santamaría Pastor, Juan Alfonso. Principios de derecho administrativo general, t. II. Madrid: Iustel, 2005.

Sayagues Areco, Alberto. El nuevo régimen de compras. Montevideo: F.C.U., 1991.

Sayagues Areco, Alberto. Reformas al sistema de compras estatales. Montevideo: Alberto Sauagués, 2011. 
Sayagues Laso, Enrique. La licitación pública. Montevideo: Acali, 1978.

Sayagues Laso, Enrique. Tratado de derecho administrativo, t. I. Montevideo: Barreiro y Ramos, 1963.

Veloso Giribaldi, Natalia. "Especificidades de los proyectos mineros de gran porte". En Carlos E. Delpiazzo y Hernán Celorrio (coords.), Derecho minero uruguayo. Montevideo: A.M.F., 2015.

Vergara Blanco, Alejandro. El derecho administrativo como sistema autónomo. El mito del Código Civil como derecho común. Santiago: Legal Publishing Chile, 2010.

Vescovi, EnRIQUe. Derecho procesal civil, t. III. Montevideo: Idea, 1975.

Vescovi, Enrique (dir.). Código General del Proceso comentado, anotado y concordado, t. 2. Montevideo: Abaco, 1993. 